RUST AND LEAF SPOT DISEASES ON AMERICAN ELDERBERRY PLANTS

A Thesis
Presented to
The Faculty of the Graduate School
At the University of Missouri

In Partial Fulfillment

Of the Requirements for the Degree

Master of Science

By

KALEY HENSEL

Dr. Michele Warmund, Thesis Supervisor

MAY 2017 
The undersigned, appointed by the Dean of the Graduate School, have examined the Thesis entitled

\section{RUST AND LEAF SPOT DISEASES ON AMERICAN ELDERBERRY PLANTS}

Presented by Kaley Hensel

A candidate for the degree of

\section{Master of Science}

And hereby certify that, in their opinion, it is worthy of acceptance.

Dr. Michele Warmund

Dr. Jeanne Mihail

Dr. J.W. Van Sambeek 


\section{ACKNOWLEDGEMENTS}

I would like to express my gratitude to Dr. Michele Warmund for her devotion, assistance, and advisement during the last two years while completing my Master's degree. I am very thankful for the opportunity and experience Dr. Warmund has given me. Overall, I have acquired new knowledge and experiences that have allowed me to develop a new skill set, making me a more well-rounded individual. Her guidance and structure strengthened my professional skills and I am very thankful for that.

I am also very thankful for Dr. Jeanne Mihail for her devoted support, kind words, and for teaching me an incredible amount about plant science and fungi. Dr. Mihail is an extraordinary teacher with a fabulous teaching style and I have enjoyed learning from her during the course of the last two years. Dr. Mihail also generously welcomed me into her lab, and I am thankful for the opportunity to utilize my new found mycology skills which have allowed me to complete my research projects.

Dr. Jerry Van Sambeek has been a wonderful committee member and I have enjoyed our conversations. I have appreciated all his advice, comments, and critiques. I am also very thankful for his time helping me prepare the micrometeorological stations at HARC, and all the additional help regarding the micrometerological stations and software.

I would like to thank all the staff, employees, and students out at HARC who have helped me tremendously during the course of my studies. I am so incredibly thankful for everyone who has helped me maintain my experiments, take data, harvest elderberries, and count elderberries! I feel very lucky that my studies were located at HARC and I enjoyed spending time with all of the wonderful people who work there. Also, I would 
like to thank John Uhlig for generously allowing me to conduct research at his beautiful elderberry planting. Working in a commercial elderberry planting provided me with a wealth of information about elderberry and rust which has tremendously supported my graduate studies.

I thank Dr. Mark Ellersieck for his incredible help with my statistics. Having his guidance made my statistics very approachable and I am very appreciative of his expertise in statistics. I also thank Patti Hosack for her encouragement and assistance in the Plant Diagnostic Lab during the course of my studies.

Finally, I would like to thank my very supportive and encouraging friend, Tim Weber! His help throughout my time spent at Mizzou has been outstanding and I am so thankful to have him in my life and cannot wait for what our farm endeavors have in store! 


\section{TABLE OF CONTENTS}

Acknowledgements.........................................................

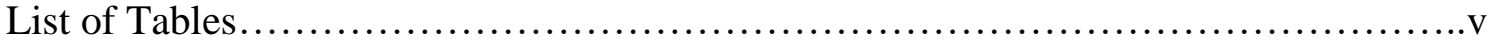

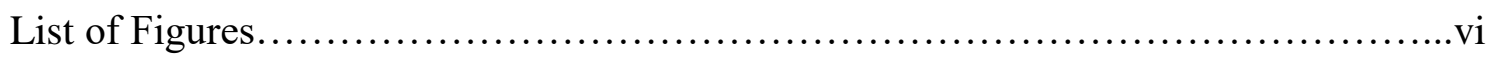

Abstract.................................................................... vii

Chapter 1: Elderberry Literature Review.......................................1

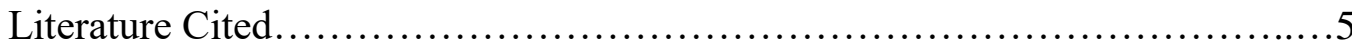

Chapter 2: Elderberry Rust Studies............................................8

Introduction......................................................

Materials and Methods................................................. 9

Results......................................................... 17

Discussion........................................................ 28

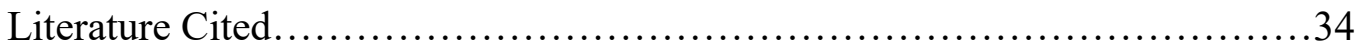

Chapter 3: Elderberry Leaf Spot Study...................................... 36

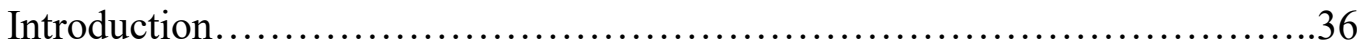

Materials and Methods.................................................. 38

Results.............................................................43

Discussion.................................................... 45

Literature Cited...................................................49

Chapter 4: Summary and Conclusions........................................53 


\section{LIST OF TABLES}

Table

Page

1. Continuous elderberry leaf wetness periods with corresponding mean maximum hourly temperatures and precipitation recorded at the Horticulture and Agroforestry Research Center near New Franklin, MO during spring 2016........18

2. Mean number of Puccinia sambuci infected leaves, leaflets, and rust pustules on 'Bob Gordon' elderberry plants at three spacings from Carex frankii (Frank's sedge) plants on 29 Apr. 2016

3. Vegetative and fruiting characteristics of 'Bob Gordon' elderberry plants with or without Puccinia sambuci rust infection.................................21

4. Mean soluble solids, $\mathrm{pH}$, and titratable acidity of berry puree from 'Bob Gordon' elderberry plants with or without Puccinia sambuci rust infection...............22

5. Vegetative and fruiting characteristics of 'Ozark' elderberry plants with or without Puccinia sambuci rust inoculation.

6. Mean soluble solids, $\mathrm{pH}$, and titratable acidity of berry puree from 'Ozark' elderberry plants with or without Puccinia sambuci rust inoculation.............24

7. Vegetative and fruiting characteristics of 'Wyldewood' canes with and without Puccinia sambuci rust infection.

8. Mean soluble solids, $\mathrm{pH}$, and titratable acidity of berry puree from 'Wyldewood' elderberry canes with or without Puccinia sambuci rust infection................28 


\section{LIST OF FIGURES}

Figure

Page

1. Experimental design for potted Sambucus nigra subsp. canadensis, 'Bob Gordon' elderberry rust infection study in 2016. $\mathrm{W}=$ 'Wyldewood' elderberry plants, $\mathrm{B}=$ 'Bob Gordon' elderberry plants, $\mathrm{S}=$ Carex frankii (Frank's sedge)...........16

2. Rust pustules on 'Wyldewood' elderberry pedicels before bloom.................25

3. Rust pustules on 'Wyldewood' elderberry pedicels during harvest...............26

4. Colletotrichum lesions on infected elderberry leaflet..........................44

5. Colletotrichum conidia spores as seen under the compound microscope.........44

6. (A) Elderberry foliar symptoms of Colletotrichum kahawae subsp. ciggaro and (B) its colony morphology on half strength potato dextrose agar...............45

7. (A) Elderberry foliar symptoms of Colletotrichum aenigma and (B) its colony morphology on half strength potato dextrose agar.........................45 


\begin{abstract}
Elderberry rust (Puccinia sambuci Schewin.) Arthur (=P. bolleyana) and leaf spot diseases are frequently found in commercial American elderberry (Sambucus nigra L. subsp. canadensis L.) plantings throughout the growing season in Missouri. Thus, studies were conducted to ascertain if rust infections affect plant growth, fruiting, or berry puree quality. Rust symptoms were observed in early April at 9 to $18^{\circ} \mathrm{C}, \geq 3 \mathrm{~h}$ leaf wetness, and $\geq 85 \%$ relative humidity. When young, potted elderberry plants averaged 3 to 6 rust pustules/plant, vegetative growth was not adversely affected. However, fieldgrown elderberry plants heavily infected with rust (137 pustules/cane) lost nearly twice as many leaves as controls during the growing season, indicating rust-induced defoliation. Shoot dry weight of these heavily infected canes was also $32 \%$ less than that of controls. First and last harvest dates were advanced by the high level of rust infection on 'Wyldewood' elderberry canes, but not by low pustules numbers ( $<6$ pustules/plant) on 'Bob Gordon' or 'Ozark' plants. Similarly, berry yields were not significantly different at low infection levels, even though rust-infected 'Bob Gordon' plants had a 31\% reduction in yield with an estimated $\$ 440 /$ ha loss of income. Heavily-infected 'Wyldewood' canes had a significant loss in berry yield (47\%) and potential income (\$2,295/ha), assuming a conservative estimate of five canes/plant.

In another study, Colletotrichum was isolated from elderberry leaf spot lesions and identified before subsequent re-inoculation of elderberry plants with this pathogen. Three species of Colletotrichum (C. salicis Funkel, C. kahawae subsp. ciggaro Wollenw., and $C$. aenigma C.M. Tian \& Z. Li) were putatively identified as being casual agents of leaf spot indicating the diversity of species within this genus on elderberry plants.
\end{abstract}




\section{CHAPTER 1: ELDERBERRY LITERATURE REVIEW}

American elderberry is a relatively new specialty crop grown in Missouri (Byers et al., 2014). Historically the bark, roots, stems, flowers, and fruit of elderberry have been foraged by native people with berries used as a folk medicine (Salamon and Grulova, 2015). Elderberries contain antioxidants and have immune system-stimulating, antibacterial, antiallergic, and antiviral properties (Inami et al., 1996; Schmitzer et al., 2012; Sidor and Gramza-Michalowska, 2015). Both flowers and berries are harvested for a wide variety of processed products such as wines, juices, teas, health supplements, jams, baked goods, and dyes (Stevens, 2001).

Elderberry plants are fruit-bearing, deciduous, multi-stemmed shrubs found native to eastern and central North America (Charlebois et al., 2010). Elderberries prefer sunny sites with moist well-drained soil (Byers et al., 2014). Throughout Missouri, wild elderberry plants are found growing along roadsides and in ditches and streams since birds consume the fruit and excrete seeds (Schmitzer et al., 2012). For commercial plantings, elderberry plants are clonally-propagated by hardwood or softwood cuttings (Charlebois et al., 2010). Underground rhizomes produce new elderberry canes throughout the growing season. At maturity, plants are $\approx 3 \mathrm{~m}$ in height with canes bearing multiple lateral shoots (Yatskievych, 1999). Leaves are opposite and oddpinnately compound often having seven leaflets (Yatskievych, 1999) and bud burst occurs as early as late Feb. in Missouri (Byers et al., 2014).

Elderberry plants flower in mid-to-late June in Missouri with large cymes composed of many five-petaled, white flowers. Flowers occur on the terminal portion of 1-and 2-year old canes (Charlebois et al., 2010). Due to the late flowering habit, elderberry is not typically affected by late spring frost. Pollination of elderberry is not 
well understood, however, it is recommended that two or more cultivars are present for optimal fruit set in commercial plantings (Byers et al., 2014). Flowers lack nectaries, but extrafloral nectaries are present on elderberry stems (Mizell, 2015; Yatskievych, 1999).

Fruit is purple-black and berries typically range from 5.0 to $6.5 \mathrm{~mm}$ in diameter (Schmitzer et al., 2012). Harvest is done by hand and is labor intensive due to the variability of ripening on plants and within individual cymes. In Missouri, elderberry harvest is from late July to September. Mature elderberry plants averaged $0.86 \mathrm{~kg}$ fruit/plant when dormant-pruned annually or averaged $1 \mathrm{~kg}$ fruit/plant if pruned every other year (Thomas et al., 2009). After harvest, fruit is de-stemmed, sanitized, and frozen for later processing. The selling price for de-stemmed berries is currently $\$ 4.40 / \mathrm{kg}$ (M. Warmund, personal communication).

The characteristic purple-black color of berries is derived from anthocyanins which are a subclass of primary polyphenols (Schmitzer et al., 2012; Sidor and GramzaMichalowska, 2015). Other primary polyphenols found in berries are flavonols, phenolic acids, and proanythcynins (Sidor and Gramza-Michalowska, 2015). Fresh berries have the highest levels of primary and secondary metabolites and during processing and storage of elderberry products, the phenolic content often decreases (Johnson et al., 2015).

Berry puree and juice chemistry varies among elderberry cultivars (PerkinsVeazie et al., 2015; Thomas et al., 2013; Warmund et al., 2016). Soluble solid content of elderberry berry puree typically ranges from 8.9 to $12.5^{\circ}$ Brix and $\mathrm{pH}$ varies from 4.3 to 5.2 (Perkins-Veazie et al., 2015; Thomas et al., 2013; Warmund et al., 2016). Titratable 
acidity of berry puree is generally from 0.21 to $1.7 \mathrm{~g} / 100 \mathrm{~mL}$ citric acid (Perkins-Veazie et al., 2015; Thomas et al., 2013; Warmund et al., 2016).

Several pests have been reported for elderberry in Missouri (Byers et al., 2014). Deer often feed on elderberry leaves and shoots and birds also consume fruit. Insect damage from Japanese beetle (Popillia japonica Newman), elderberry borer (Desmocerus palliates Forster), elder shoot borer (Achatodes zeae Harris) and sawfly (Tenthrado grandis Norton) can also restrict elderberry production (Byers et al., 2014; Charlebois et al., 2010). Spotted wing drosophila (Drosophila suzukii Matsumura) has recently become an increasingly important elderberry pest (Pinero, 2013). Adult D. suzukii females lay more than 300 eggs with larval feeding causing fruit loss (Pinero, 2013; Ryan, 2010). Two species of eriophyid mites (Phyllocoptes) are also commonly found on elderberry plants in Missouri, which cause tightly-rolled leaflet margins or crinkling of the foliage (Warmund and Amrine, 2015).

Various pathogens are also found on elderberry. Pseudomonas viridiflava Brunkholder (Byers et al., 2014), Phyllosticta sambuci Desm. (Horst, 2013), Ramularia sambucina Sacc. (Horst, 2013), and Septoria sambucina Pk. (Martin, 1887) have been reported as causal organisms of leaf spot diseases on elderberry. Elderberry plants also host tomato ring spot virus (Horst, 2013) and cherry leaf roll virus (Byers et al., 2014). Two claraviruses, EBCV153 and EBCV145, have been reported on elderberry in Missouri (Keller et al., 2015). A unique rust fungus of elderberry (Puccinia sambuci) causes bright orange pustules on leaves, stems, and petioles (Arthur, 1962). The life cycle of $P$. sambuci includes five spore types, including pycniospores, aeciospores, urediniospores, teliospores, and basidiospores (Arthur, 1962). Symptoms of elderberry 
rust are first observed early in the growing season but a Carex species serves as an alternate host for this fungus in summer and through winter (Kellerman, 1904).

While several pathogens of elderberry have been noted in the literature, there is a paucity of information on fungi infecting commercial plantings in Missouri and the crop damage associated with these organisms. Thus, the purpose of this research was to document the effect of elderberry rust and leaf spot disease on commonly-grown cultivars. 


\section{LITERATURE CITED}

Arthur, J.C. 1962. Manual of the rusts in the United States and Canada. Hafner

Publishing Company, New York.

Byers, P.L., A.L. Thomas, M.A. Gold, M.M. Cernusca, and L.D. Godsey. 2014. Growing and marketing elderberries in Missouri. AF1016. 20 Jul. 2016. < http://www.centerforagroforestry.org/pubs/2014GrowingElderberryGuide.pdf > .

Charlebois, D., P.L. Byers, C.E. Finn, and A.L Thomas. 2010. Elderberry: botany, horticulture, potential. Hort. Rev. 37:213-280.

Horst, R.K. 2013. Westcott's Plant Disease Handbook. $8^{\text {th }}$ ed. Cornell Univ., Ithaca, N.Y. Inami, O., I. Tamura, H. Kikuzaki, and N. Nakatani. 1996. Stability of anthocyanins of Sambucus canadensis and Sambucus nigra. J. Agr. Food Chem. 44:3090-3096.

Johnson, M.C., A.L., Thomas, and C.M. Greenlief. 2015. Impact of frozen storage on the anthocyanin and polyphenol contents of American elderberry fruit juice. J. Agr. Food Chem. 63:5653-5659.

Keller, K.E., N.J. Mosier, A.L. Thomas, D.F. Quito-Avila, and R.R. Martin. 2015. Identification of two new carlaviruses in elderberry. Acta Hort. 1061:161-164.

Kellerman, W.A. 1904. Uredineous infection experiments in 1904. J. of Mycol. 11:26-33. Martin, G. 1887. Enumeration and description of the Septorias of North America. J. Mycol. 3:73-82.

Mizell, R.F. 2015. Many plants have extrafloral nectaries helpful to beneficials. 1 Apr. 2017. < http://edis.ifas.ufl.edu/in175>. 
Perkins-Veazie, P., A.L. Thomas, P.L. Byers and C.E. Finn. 2015. Fruit composition of elderberry (Sambucus spp.) genotypes in Oregon and Missouri, USA. Acta Hort. 1061:219-222.

Pinero, J. 2013. Monitoring for spotted wing drosophila, an insect pest of berries and other fruits in Missouri. Lincoln Univ. Coop. Ext. Serv. 16 July 2016. <https://ipm.missouri.edu/MEG/2013/8/Detecting-larval-infestations-andinsecticidal-options-for-Spotted-Wing-Drosophila-a-significant-pest-of-smallfruit-crops-in-Missouri/Spotted_Wing_Drosophila.PDF>.

Ryan, S.D. 2010. Spotted Wing Drosophila. Utah State Univ. Ext. 16 July 2016. $<$ http://citeseerx.ist.psu.edu/viewdoc/download?doi=10.1.1.729.1106\&rep=rep1\& type $=\mathrm{pdf} />$.

Saccardo, P.A. 1891. Sylloge fungorum omnium hucusque cognitorum. R. Friedlander \& Sohn, Berlin.

Salamon, I. and D. Grulova. 2015. Elderberry (Sambucus nigra): from natural medicine in ancient times to protection against witches in the middle ages- a brief historical overview. Acta Hort. 1061:35-39.

Schmitzer, S., R. Veberic, and F. Stampar. 2012. European elderberry (Sambucus nigra L.) and American elderberry (Sambucus canadensis L.): botanical, chemical and health properties of flowers, berries and their properties, p. 127-148. In: Carlo Tuberoso (ed.). Berries: properties, consumption and nutrition. Nova Science Publishers, Inc. Hauppauge, N.Y. 
Sidor, A., and A. Gramza-Michalowska. 2015. Advanced research on the antioxidant and health benefit of elderberry (Sambucus nigra) in food- a review. J. Functional Foods 18:941-958.

Stevens, M. 2001. Plant Guide for common elderberry (Sambucus nigra L. subsp. canadensis L.) R. Bolli. USDA-Natl. Resources Conservation Serv. Natl. Plant Data Center, Baton Rouge, La. 20 July 2017.< https://plants.usda.gov/plantguide/pdf/cs_sanic4.pdf>.

Thomas A.L., P.L. Byers, and M.R. Ellersieck. 2009. Productivity and characteristics of American elderberry in response to various pruning methods. HortScience 44:671-677.

Thomas A.L., P. Perkins-Veazie, P.L. Byers, C.E. Finn, and J. Lee. 2013. A comparison of fruit characteristics among diverse elderberry genotypes grown in Missouri and Oregon. J. Berry Res. 3:159-168.

Warmund, M.R., and J.W. Amrine. 2015. Eriophyid mites inhabiting American elderberry. Acta Hort. 1061:155-159.

Warmund, M., M. Kwasniewski, J. Elmore, A. Thomas, and K. Adhikari. 2016. Sensory attributes of juice from North American-grown elderberry cultivars. HortScience $51: 1561-1565$.

Yatskievych, G. 1999. Steyermark’s Flora of Missouri. Vol. 1. Missouri Botanical Garden Press, St. Louis. 


\section{CHAPTER 2: ELDERBERRY RUST STUDIES}

\section{INTRODUCTION}

Elderberry rust, Puccinia sambuci Schewin. Arthur (= P. bolleyana), is found on American elderberry in the eastern United States (Arthur, 1962; Kellerman, 1904). Symptoms of $P$. sambuci on elderberry occur as gall-like swellings on leaves, stems, and petioles (Arthur, 1962). P. sambuci is a heteroecious fungus which requires two alternate hosts, a sedge (Carex spp.) and American elderberry (Mims, 1981; Saccardo, 1891). Twelve species of sedge have been reported as the alternate host for P. sambuci, including C. bebbii, C. bulata, C. comosa, C. crinite, C. crus-corvi, C. frankii, C. intumescens, C. lupulina, C. lupuliformis, C. lurida, C. tribuloides, and C. trichocarpa (Arthur, 1962). The five spore stages of $P$. sambuci are pycniospores, aeciospores, urediniospores, teliospores, and basidiospores (Arthur, 1962).

Pycnia are the first symptoms observed on elderberry leaflets and petioles in early spring and appear as small yellow pustules. Pycnia are flask-shaped and contain receptive hyphae and pycniospores (Peterson, 1974; Littlefield and Heath, 1979). Pycniospores cannot infect elderberry tissue alone, instead, they must encounter receptive hyphae of a compatible mating type which undergo plasmogamy, resulting in the formation of dikaryotic mycelium (Mims, 1981).

After dikaryotization, mycelia grow intracellularly to the underside of the plant tissue using intracellular haustoria to gain nutrients and develop spore-producing aecia (Mims, 1981; Petersen, 1974). P. bollyana aecia are often observed on elderberry in May

with large pustules causing deformed leaves, stems, and petioles. Aecia produce chains of 
aeciospores which are wind blown to the alternate host, a Carex species (sedge) (Mims, 1981).

After germination on susceptible sedge leaf tissue in the summer, urediniospores formed within uredinia, continue to infect sedge plants (Bolley, 1889). In the late summer, sexual, two-celled teliospores are produced with thick cell walls to withstand colder winter temperatures (Arthur, 1962). Upon conducive conditions in March or April, each cell of the teliospore germinates and produces a basidium, the site of meiosis, resulting in four haploid basidiospores which are wind blown to elderberry plants (Petersen, 1974). Basidospore germination occurs laterally on elderberry tissue and a germ tube is produced, penetrating the host directly through the cuticle and epidermis with subsequent formation of haploid mycelium that forms pycnia (Agrios, 2005).

Although the disease cycle of $P$. sambuci has been described, the epidemiology of elderberry rust has not been investigated. Thus, studies were conducted in 2016 to ascertain environmental conditions associated with elderberry rust infection and determine the effect of this fungus on vegetative growth and fruiting. Additionally, the effect of $P$. sambuci on elderberry berry puree after harvest was evaluated.

\section{MATERIALS AND METHODS}

Collection of P. sambuci-infected plants. Twenty-five sedge plants (Carex frankii Kunth) infected with $P$. sambuci teilospores were obtained from a commercial elderberry planting near Hartsburg, MO in Oct. 2014, placed into 8.5 L polyethylene containers (A.M. Leonard, Piqua, $\mathrm{OH}$ ) with native soil (Haymond silt loam) and transported to the MU Horticulture and Agroforestry Research Center (HARC) near New Franklin, MO. 
Plants were maintained in a nursery area until they were covered with a polyethylene foam blanket (Hummerts, St. Louis, MO) and plastic sheeting for winter protection on 26 Nov. 2014. Two-year-old 'Bob Gordon' elderberry plants in 8.5 L polyethylene containers (A.M Leonard, Piqua, OH), that had been propagated from the same site were overwintered similarly. Sedge and elderberry plants were uncovered on 10 Mar. 2015 and were randomly interspersed in the nursery area to maintain $P$. sambuci. Plants were irrigated as needed throughout the growing season. By summer 2015, P. sambuci urediniospores from the elderberry plants had reinfected the sedge plants.

Rust infection of potted 'Bob Gordon' plants in 2016. 'Bob Gordon' and 'Wyldewood' elderberry plants were obtained from a commercial source (Botany Shop, Joplin, MO) on 11 Nov. 2015, transported to HARC, and then transplanted on 14 Nov. 2015 into 8.5 L polyethylene containers (A.M Leonard, Piqua, OH) using Pro-Mix BX (Premier Tech Horticulture, Quakertown, PA). On 20 Nov. 2015, elderberry plants were overwintered as previously described. Sedge plants maintained in the nursery area during the growing season were isolated from elderberry plants during overwintering to prevent an early rust infection.

Plants were uncovered on 11 Mar. 2016. Dormant oil (Damoil®; Drexel Chemical Company, Memphis, TN) was applied to elderberry plants for control of overwintering eriophyid mites (Phyllocoptes wisconsinensis Kiefer) at $7.5 \mathrm{~mL}$ a.i. $\cdot \mathrm{L}^{-1}$ on 14 Mar. 2016. Elderberry plants were fertilized with 50 g 15N-9P-12K controlled-release fertilizer (Osmocote ${ }^{\circledR}$; Scotts Company, Marysville, OH) on 21 Mar. 2016 and pruned to five nodes on 28 Mar. 2016. 
To infect elderberry plants with P. sambuci, plants that were obtained in Nov. 2015 were arranged in six experimental blocks with four $C$. frankii sedge plants centrally located within each block. Each block contained 12 'Bob Gordon' elderberry plants with three in each north, south, east, and west orientation (Fig. 1). One block similarly arranged, but without the sedge was used for uninfected controls. Elderberry plants were arranged pot to pot, approximately $10 \mathrm{~cm}$ from each other. For pollination, one 'Wyldewood' elderberry plant was placed in the northwest, southwest, and southeast quadrant of each block. A clear polyethylene curtain (2.5-m-tall) was placed between blocks with and without sedge plants to prevent rust infection of control plants. Plants were sub-irrigated by filling 4 L saucers (Hummert; St. Louis) underneath pots as needed. After pycnia and aecia were observed on elderberry, all plants were moved to a nursery area with overhead irrigation and were arranged in a completely randomized design on 25 July 2016. From 22 Mar. 2016 to 25 July 2016, spirodiclofen (Envidor® 2 SC; Bayer, Research Triangle Park, NC) was applied at $240 \mathrm{~g} / \mathrm{L}$ a.i. at 10 to $14 \mathrm{~d}$ intervals for mite control.

Micrometeorological data were recorded from 26 Feb. 2016 to 28 Sept. 2016 using a data logger remote monitoring system (U30; Onset, Bourne, MA) located $1 \mathrm{~m}$ east of the rust infected blocks. Temperature (S-TMB-M006; Onset, Bourne, MA), relative humidity (S-TMB-M006; Onset, Bourne, MA), and leaf wetness (S-LWA-M003 Onset; Bourne, MA) were recorded at $10 \mathrm{~s}$ intervals, averaged, and logged at $10 \mathrm{~min}$ intervals. Based upon the results of Beraha et al. (1960), temperatures $>8^{\circ} \mathrm{C}$, relative humidity $\geq 85 \%$, and leaf wetness periods $\geq 3 \mathrm{~h}$ were evaluated to determine infection periods. 
After each fruit harvest, destemmed berries were stored at $-22^{\circ} \mathrm{C}$. For fruit compositional analyses, berries from each elderberry plant were pooled after thawing. A $50 \mathrm{~g}$ fruit sample from each plant was placed in a blender cup (Waring; Conair Corporation, Stamford, CT) with $50 \mathrm{~mL}$ double distilled water and processed for $30 \mathrm{~s}$. Puree was then pressed through a mesh sieve to remove seeds. When harvested fruit was less than 50 g per plant, a 1 fruit: 1 double distilled water (w/v) sample was prepared. Soluble solids concentrations were determined with a digital refractometer (PAL-1; ATAGO USA, Bellevue, WA), using a $0.3 \mathrm{~mL}$ aliquot of puree. For $\mathrm{pH}$ measurements (HI222; Hanna Instruments, Woonsocket, RI) a $10 \mathrm{~mL}$ aliquot of puree was used. Another $2 \mathrm{~mL}$ aliquot of puree was mixed with $48 \mathrm{~mL}$ degassed deionized water and automatically titrated (G20 Compact Titrator; Mettler-Toledo, LLC, Columbus, OH) to an endpoint $\mathrm{pH}$ of 8.2 with $0.1 \mathrm{~N}$ sodium hydroxide. Titratable acidity (TA), expressed as citric acid, was then calculated.

To evaluate the effect of four orientations and three placements of 'Bob Gordon' plants $(1=$ closest to sedge plants to $3=$ furthest from sedge plants $)$ on rust pustule development, data were analyzed as a 4 x 3 factorial experiment, using PROC GLMMIX procedure of SAS (Version 9.4; SAS Institute, Cary, N.C.). Means were separated by Fisher's protected least significant difference test (LSD), $P \leq 0.05$. Because of the relatively low incidence of rust pustules on 'Bob Gordon' elderberry plants, the T TEST procedure of SAS was used to statistically analyze the effect of $P$. sambuci on plant growth and fruiting. To test mean differences, a pooled test was used when variances were equal and the Satterthwaite test was used when variances were unequal, $P \leq 0.05$. 
P. sambuci inoculation of potted 'Ozark' plants. Thirty-two 'Ozark' elderberry plants were obtained from a commercial source (Botany Shop, Joplin, MO) on 23 Mar. 2016, transported to HARC, and then transplanted to 8.5 L polyethylene containers (A.M Leonard, Piqua, $\mathrm{OH}$ ) using Pro-Mix BX (Premier Tech Horticulture, Quakertown, PA. Elderberry plants were treated with dormant oil on 14 Mar. 2016 and fertilized on 21 Mar. 2016 as previously described before pruning to six nodes on 28 Mar. 2016.

On 8 Apr. 2016 potted sedge plants, maintained as previously described, were used as a source of $P$. sambuci inoculum. Sections $(1 \mathrm{~cm} \mathrm{x} 1 \mathrm{~cm})$ of rust-infected sedge leaves were used to inoculate 'Ozark' elderberry leaflets at three levels. For low, medium, and high inoculation levels, either two, four, or eight elderberry leaflets, respectively, were smeared with a rust-infected foliar section of sedge after each elderberry plant was sprayed with $30 \mathrm{~mL}$ sterile water. Immediately after inoculation, potted elderberry plants were placed on an inverted $8.5 \mathrm{~L}$ polyethylene container and sealed in $208 \mathrm{~L}$ trash bags containing $10 \mathrm{~L}$ of water to maintain high humidity during incubation. Eight plants were inoculated for each rust treatment. Another eight plants were sprayed with $30 \mathrm{~mL}$ sterile water (i.e., controls) before bagging. All plants were incubated at $17^{\circ} \mathrm{C}$ for $48 \mathrm{~h}$. After incubation, plants were arranged in a randomized complete block design (RCBD) in the nursery area at HARC and maintained as previously described. Plants were sub-irrigated by filling 4 L saucers (Hummert; St. Louis) underneath pots as needed.

Total leaf number, number of $P$. sambuci-infected leaves, and number of pustules per infected leaf were recorded on 29 Apr. 2016 and 19 May 2016. Date of flowering and fruit harvest (8 Aug. 2016 to 28 Sept. 2016), berry number, and berry weight were 
also recorded throughout the season. On 19 Aug. 2016, the number of leaves per elderberry plant was recorded. Plants were pruned to $10 \mathrm{~cm}$ above soil surface and shoot dry weights were recorded on 10 Oct. 2016. Fruit compositional analyses were performed as described above.

Elderberry plant growth, fruiting, and fruit compositional data were subjected to ANOVA, using the PROC GLM procedure of SAS. Because significant differences between levels of rust infection were not found, infection data were pooled and the $\mathrm{T}$ TEST procedure of SAS was used to analyze effects of rust on infected versus uninfected elderberry canes. To test mean differences, a pooled test was used when variances were equal and the Satterthwaite test was used when variances were unequal, $P \leq 0.05$.

Natural rust infection of 'Wyldewood' elderberry canes at a commercial elderberry planting. Three-year-old 'Wyldewood' elderberry plants growing in a Weller silt loam soil in a commercial planting near New Bloomfield, MO were used for this study. Eleven elderberry canes of each of three $P$. sambuci rust infection levels (high, medium, and low) were visually assessed and flagged on 18 May 2016. Eleven individual canes of each infection level and uninfected controls without rust were also flagged in a completely randomized design. Total leaf number, number of $P$. sambuciinfected leaves, and number of pustules per leaf on each elderberry cane were recorded on 31 May 2016. The number of leaves on control canes were also recorded at this time. Fruit harvest, berry number, and berry weight were recorded from 20 July 2016 to 23 Aug. 2016. Leaves of each cane were counted on 26 Aug. 2016. Canes were pruned to $10 \mathrm{~cm}$ and the plant material was harvested for dry weight measurements on 13 Oct. 2016. Fruit compositional analysis was performed as described above. 
Elderberry plant growth, fruiting, and fruit compositional data were subjected to ANOVA, using the PROC GLM procedure of SAS. Because significant differences between levels of rust infection were not found, infection data were pooled and the $\mathrm{T}$ TEST procedure of SAS was used to analyze effects of rust on infected versus uninfected elderberry canes. To test mean differences, a pooled test was used when variances were equal and the Satterthwaite test was used when variances were unequal, $P \leq 0.05$. 


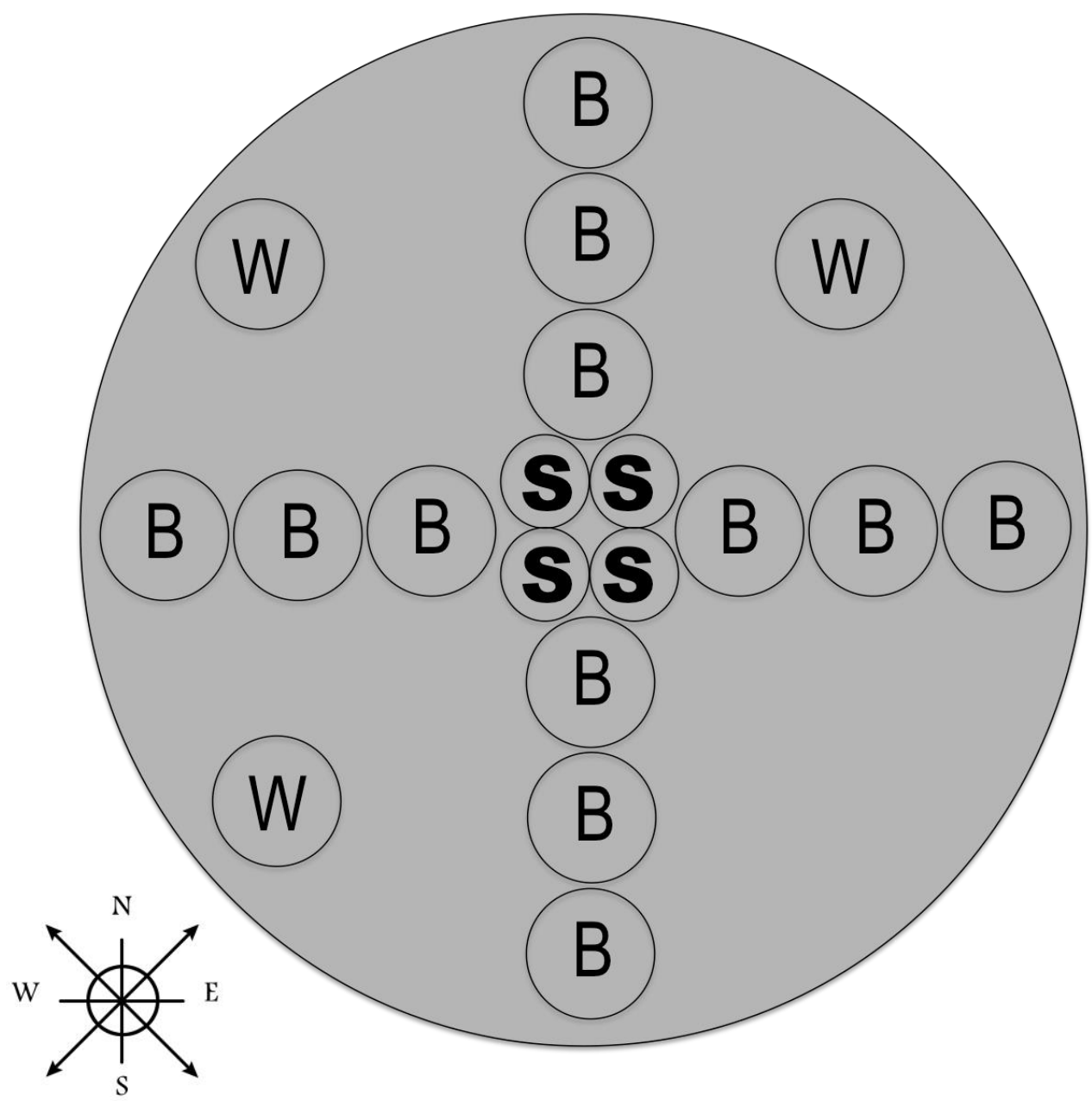

Fig. 1. Experimental design for potted Sambucus nigra subsp. canadensis, 'Bob Gordon' elderberry rust infection study in 2016. W= 'Wyldewood' elderberry plants, $\mathrm{B}=$ 'Bob Gordon' elderberry plants, $\mathrm{S}=$ Carex frankii (Frank's sedge). 


\section{RESULTS}

Potential infection periods of $P$. sambuci. From the time elderberry plants were uncovered to 19 May 2016, there were 30 potential infection periods with $\geq 3 \mathrm{~h}$ of continuous leaf wetness and mean maximum hourly temperatures ranging from 9 to $17^{\circ}$ C (Table 1). Also, $269 \mathrm{~mm}$ of rainfall was recorded during 13 precipitation events. A few rust pustules were first observed on four of 72 'Bob Gordon' elderberry plants on 5 Apr. 2016. However, by 29 Apr. 2016, 59 of 72 plants were infected with rust, with a total of 304 pustules. Rust infection continued and 63 of 72 elderberry plants with 350 total pustules were recorded on 19 May 2016. 
Table 1. Continuous elderberry leaf wetness periods with corresponding mean maximum hourly temperatures and precipitation recorded at the Horticulture and Agroforestry Research Center near New Franklin, MO during spring 2016.

\begin{tabular}{|c|c|c|c|}
\hline Date $^{z}$ & $\begin{array}{l}\text { Continuous leaf } \\
\text { wetness } \\
\text { (no. of hours) }\end{array}$ & $\begin{array}{l}\text { Mean hourly temp. } \\
\text { during wetness } \\
\text { period } \\
\left({ }^{\circ} \mathrm{C}\right)\end{array}$ & $\begin{array}{l}\text { Precipitation during } \\
\text { leaf wetness period } \\
(\mathrm{mm})\end{array}$ \\
\hline $3 / 12$ & 3 & 12.5 & 3.1 \\
\hline $3 / 12$ to $3 / 13$ & 18 & 13.2 & 5.6 \\
\hline $3 / 13$ to $3 / 14$ & 13 & 10.9 & 0 \\
\hline $3 / 14$ to $3 / 15$ & 13 & 11.4 & 0 \\
\hline $3 / 31$ & 7.5 & 13.1 & 5.1 \\
\hline $4 / 6$ & 3 & 13.3 & 0.5 \\
\hline $4 / 10$ to $4 / 11$ & 13 & 11.9 & 17.5 \\
\hline $4 / 16$ & 5 & 10.8 & 0 \\
\hline $4 / 16$ & 10 & 10.8 & 0 \\
\hline $4 / 17$ & 11 & 12.3 & 0 \\
\hline $4 / 18$ to $4 / 19$ & 16 & 16.2 & 58.7 \\
\hline $4 / 19$ to $4 / 20$ & 11 & 15.0 & 35.1 \\
\hline $4 / 20$ to $4 / 21$ & 13 & 9.7 & 0 \\
\hline $4 / 22$ & 9 & 8.9 & 0 \\
\hline $4 / 23$ & 11 & 11.4 & 0 \\
\hline $4 / 25$ to $4 / 26$ & 10 & 16.2 & 0 \\
\hline $4 / 26$ & 3 & 15.4 & 0 \\
\hline $4 / 27$ & 3 & 15.8 & 1.9 \\
\hline $4 / 27$ & 4 & 12.4 & 0 \\
\hline $4 / 29$ to $4 / 30$ & 15 & 14.2 & 34.5 \\
\hline $5 / 1$ & 8.5 & 12.0 & 0 \\
\hline $5 / 6$ to $5 / 7$ & 9.5 & 12.2 & 0 \\
\hline $5 / 7$ & 3 & 17.8 & 0 \\
\hline $5 / 8$ & 7 & 14.3 & 0 \\
\hline $5 / 8$ to $5 / 9$ & 16 & 17.1 & 0 \\
\hline $5 / 9$ to $5 / 10$ & 11 & 16.0 & 6.9 \\
\hline $5 / 10$ to $5 / 11$ & 14 & 16.1 & 1.0 \\
\hline $5 / 12$ & 5 & 14.4 & 0 \\
\hline $5 / 15$ to $5 / 16$ & 10 & 11.2 & 17.3 \\
\hline $5 / 16$ to $5 / 17$ & 22 & 10.4 & 81.8 \\
\hline
\end{tabular}

${ }^{\mathrm{R}}$ Rust pustules $(\approx 5)$ were first observed on elderberry plants on 5 Apr. By 29 Apr., a total of 304 pustules were observed on 59 plants and 350 total pustules were observed on 19 May on 63 plants. 
Rust infection of potted 'Bob Gordon' plants. During the growing season, 30 'Bob Gordon' elderberry plants were excluded from the study due to deer herbivory or cane dieback from an unknown disease. 'Bob Gordon' plants had relatively low levels of rust infection when evaluated on 29 Apr. 2016 (Table 2). However, elderberry plants spaced $10 \mathrm{~cm}$ from sedge had more infected leaves and leaflets, and a greater number of pustules per plant than those spaced at $20 \mathrm{~cm}$ and $30 \mathrm{~cm}$. Also, the orientation of plants in each block (north, south, east, and west) did not affect the number of infected leaves or leaflets or pustules per plant (data not shown).

Table 2. Mean number of $P$. sambuci infected leaves, leaflets, and rust pustules on 'Bob Gordon' elderberry plants at three spacings from Carex frankii (Frank's sedge) plants on 29 Apr. 2016. ${ }^{\mathrm{Z}}$

\begin{tabular}{cccc}
\hline $\begin{array}{c}\text { Spacing from sedge } \\
(\mathrm{cm})\end{array}$ & $\begin{array}{c}\text { No. of infected } \\
\text { leaves/plant }\end{array}$ & $\begin{array}{c}\text { No. of infected } \\
\text { leaflets/plant }\end{array}$ & $\begin{array}{c}\text { No. of } \\
\text { pustules/plant }\end{array}$ \\
\hline 10 & $3.3 \mathrm{a}$ & $5.8 \mathrm{a}$ & $7.6 \mathrm{a}$ \\
20 & $1.7 \mathrm{~b}$ & $2.5 \mathrm{~b}$ & $3.5 \mathrm{~b}$ \\
30 & $2.8 \mathrm{ab}$ & $3.4 \mathrm{ab}$ & $3.9 \mathrm{~b}$ \\
\hline
\end{tabular}

${ }^{\mathrm{z}}$ Means represent 24 replications of each spacing from sedge. Mean separation within columns by Fisher's protected LSD test $(P \leq 0.05)$.

By 19 May 2016, the number of infected leaves, leaflets, and pustules per elderberry plant did not differ by plant spacing or orientation. However, when data for rust-infected plants were pooled, the number of pustules per plant ranged from one to 27 $(\bar{x}=6)$. Leaf number of rust-infected plants was also less than that of uninfected plants (Table 3).

The first dates of flowering were similar for all plants, occurring in the last week of June (Table 3). First and last harvest dates for rust-infected plants and uninfected plants were also similar. The mean number of cymes produced on rust-infected plants was three, averaging 761 berries, whereas the mean number of cymes for uninfected plants was two, averaging 930 berries. Mean berry weight from rust-infected plants was 
$11 \mathrm{mg}$ less than that from uninfected plants (Table 3). On 19 Aug., leaf numbers were similar among infected and uninfected plants. However, shoot dry weight of rustinfected plants was greater than that of uninfected plants.

When berry puree characteristics were analyzed, there were no significant

differences among treatments (Table 4). Numerically, soluble solid content was $0.6^{\circ}$ Brix lower and titratable acidity was $0.2 \mathrm{~g} / 100 \mathrm{~mL}$ higher for rust-infected plants as compared to berry puree from uninfected plants (Table 4). 
Table 3. Vegetative and fruiting characteristics of 'Bob Gordon' elderberry plants with or without $P$. sambuci rust infection. ${ }^{\mathrm{Z}}$

\begin{tabular}{|c|c|c|c|c|c|c|c|c|c|}
\hline Treatment & $\begin{array}{l}\text { Leaf } \\
\text { no. }^{\mathrm{y}}\end{array}$ & $\begin{array}{c}\text { First } \\
\text { flowering } \\
\text { date }^{\mathrm{x}}\end{array}$ & $\begin{array}{c}\text { First } \\
\text { harvest } \\
\text { date }^{\mathrm{x}}\end{array}$ & $\begin{array}{c}\text { Last } \\
\text { harvest } \\
\text { date }^{\mathrm{x}} \\
\end{array}$ & $\begin{array}{c}\text { Berry } \\
\text { no. }\end{array}$ & $\begin{array}{c}\text { Berry } \\
\text { yield } \\
(\mathrm{g}) \\
\end{array}$ & $\begin{array}{c}\text { Mean } \\
\text { berry wt. } \\
(\mathrm{mg})\end{array}$ & $\begin{array}{l}\text { Leaf } \\
\text { no. }{ }^{w}\end{array}$ & $\begin{array}{c}\text { Shoot dry } \\
\text { wt. }^{\mathrm{v}} \\
\text { (g) }\end{array}$ \\
\hline Rust-infected & $37 \mathrm{a}$ & $181 \mathrm{a}$ & $225 \mathrm{a}$ & $236 \mathrm{a}$ & $761 \mathrm{a}$ & $84 \mathrm{a}$ & $116 \mathrm{a}$ & $77 \mathrm{a}$ & $48.6 \mathrm{a}$ \\
\hline Uninfected & $31 \mathrm{~b}$ & $183 \mathrm{a}$ & $221 \mathrm{a}$ & $238 \mathrm{a}$ & $930 \mathrm{a}$ & $121 \mathrm{a}$ & $127 \mathrm{~b}$ & $73 \mathrm{a}$ & $31.4 \mathrm{~b}$ \\
\hline
\end{tabular}

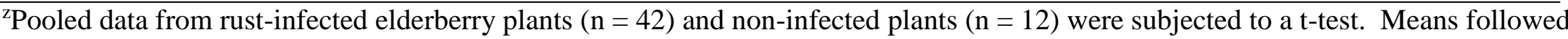
by different letters are significantly different $(P \leq 0.05)$. Mean separation within columns by Satterthwaite test when variances were unequal, or by a pooled test when variances were equal. Rust-infected plants averaged six pustules/plant.

${ }^{\mathrm{y}}$ Number of leaves/plant on 19 May 2016.

${ }^{\mathrm{x}}$ Values represent Julian days.

${ }^{w}$ Number of leaves/plant on 19 Aug. 2016.

v'Shoots harvested $10 \mathrm{~cm}$ above media surface on 10 Oct. 2016. 
Table 4. Mean soluble solids, $\mathrm{pH}$, and titratable acidity of berry puree from 'Bob Gordon' elderberry plants with or without $P$. sambuci rust infection. ${ }^{\mathrm{z}}$

\begin{tabular}{lccc}
\hline Treatment & $\begin{array}{c}\text { Soluble solids } \\
\left({ }^{\circ} \text { Brix }\right)\end{array}$ & $\mathrm{pH}$ & $\begin{array}{c}\text { Titratable acidity } \\
(\mathrm{g} / 100 \mathrm{~mL} \text { as citric acid })\end{array}$ \\
\hline Rust-infected & $10.6 \mathrm{a}$ & $5.0 \mathrm{a}$ & $0.68 \mathrm{a}$ \\
Uninfected & $11.2 \mathrm{a}$ & $5.1 \mathrm{a}$ & $0.48 \mathrm{a}$ \\
\hline
\end{tabular}

${ }^{\mathrm{z} P o o l e d ~ d a t a ~ f r o m ~ r u s t-i n f e c t e d ~ e l d e r b e r r y ~ p l a n t s ~}(\mathrm{n}=42)$ and non-infected plants $(\mathrm{n}=$ 12) were subjected to a t-test. Means followed by similar letters are not significantly different $(P \leq 0.05)$. Mean separation within columns by Satterthwaite test when variances were unequal, or by a pooled test when variances were equal. Rust-infected plants averaged six pustules/plant.

P. sambuci inoculation of potted 'Ozark' plants. During the growing season, 16 'Ozark' elderberry plants were excluded from the study due to deer herbivory and cane dieback from an unidentified disease. When elderberry plants were inoculated with rust using sections of rust-infected sedge tissue in April, there were no significant differences in infection severity on elderberry plants among inoculation treatments at any evaluation date. One to five pustules $(\overline{\mathrm{x}}=2.6)$ per plant were observed on 19 May 2016.

Leaf numbers were similar among plants (only varying by one leaf) on 16 May 2016. When other vegetative and fruiting characteristics were analyzed, only the first flowering date was significant with rust-inoculated plants flowering nine days earlier than non-inoculated plants (Table 5). Plants with rust had a harvest period that was five days shorter than non-inoculated plants. Both rust-inoculated and non-inoculated plants had a mean cyme number of three per plant. Numerically, plants with rust produced more fruit and larger berries than those without rust. By 19 Aug. 2016, rust-inoculated plants generally had fewer leaves than non-inoculated plants but the shoot dry weights only varied by $\approx 2.5 \mathrm{~g}$ on 10 Oct. 2016. Berry puree characteristics were similar between the treatments, but soluble solids content of berry puree from rust-inoculated plants was generally lower $\left(0.9^{\circ}\right.$ Brix $)$, than that from non-inoculated plants (Table 6). 
Table 5. Vegetative and fruiting characteristics of 'Ozark' elderberry plants with or without $P$. sambuci rust inoculation. ${ }^{\mathrm{Z}}$

\begin{tabular}{|c|c|c|c|c|c|c|c|c|c|}
\hline Treatment & $\begin{array}{l}\text { Leaf } \\
\text { no. }^{y}\end{array}$ & $\begin{array}{c}\text { First } \\
\text { flowering } \\
\text { date }^{\mathrm{x}}\end{array}$ & $\begin{array}{c}\text { First } \\
\text { harvest } \\
\text { date }^{\mathrm{x}}\end{array}$ & $\begin{array}{c}\text { Last } \\
\text { harvest } \\
\text { date }^{\mathrm{x}}\end{array}$ & Berry no. & $\begin{array}{c}\text { Berry } \\
\text { yield } \\
(\mathrm{g}) \\
\end{array}$ & $\begin{array}{c}\text { Mean } \\
\text { berry wt. } \\
(\mathrm{mg})\end{array}$ & $\begin{array}{l}\text { Leaf } \\
\text { no. }{ }^{w}\end{array}$ & $\begin{array}{c}\text { Shoot } \\
\text { dry wt. } \\
(\mathrm{g})^{\mathrm{v}} \\
\end{array}$ \\
\hline Rust-inoculated & $43 \mathrm{a}$ & $179 \mathrm{a}$ & $227 \mathrm{a}$ & $239 a$ & $1129 \mathrm{a}$ & $109 \mathrm{a}$ & $165 \mathrm{a}$ & $61 \mathrm{a}$ & $36.3 \mathrm{a}$ \\
\hline Non-inoculated & $44 \mathrm{a}$ & $188 \mathrm{~b}$ & $235 \mathrm{a}$ & $252 \mathrm{a}$ & $621 \mathrm{a}$ & $70 \mathrm{a}$ & $117 \mathrm{a}$ & $80 \mathrm{a}$ & $38.8 \mathrm{a}$ \\
\hline
\end{tabular}

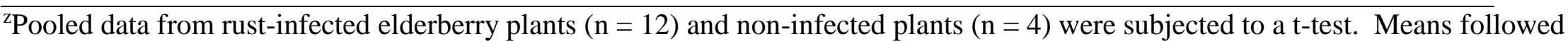
by different letters are significantly different $(P \leq 0.05)$. Mean separation within columns by Satterthwaite test when variances were unequal, or by a pooled test when variances were equal. Rust-infected plants averaged 2.6 pustules/plant.

${ }^{\mathrm{y}}$ Number of leaves/plant on 19 May 2016.

${ }^{x}$ Values represent Julian days.

wNumber of leaves/plant on 19 Aug. 2016.

${ }^{v}$ Shoots harvested $10 \mathrm{~cm}$ above media surface on 10 Oct. 2016. 
Table 6. Mean soluble solids, $\mathrm{pH}$, and titratable acidity of berry puree from 'Ozark' elderberry plants with or without $P$. sambuci rust inoculation. ${ }^{\mathrm{Z}}$

\begin{tabular}{lccc}
\hline & $\begin{array}{c}\text { Soluble solids } \\
\left({ }^{\circ} \mathrm{Brix}\right)\end{array}$ & $\mathrm{pH}$ & $\begin{array}{c}\text { Titratable acidity } \\
(\mathrm{g} / 100 \mathrm{~mL} \text { as citric acid })\end{array}$ \\
\hline Treatment & $10.9 \mathrm{a}$ & $4.6 \mathrm{a}$ & $0.70 \mathrm{a}$ \\
Rust-inoculated & $11.8 \mathrm{a}$ & $4.6 \mathrm{a}$ & $0.72 \mathrm{a}$ \\
Non-inoculated & "2Pooled data from rust-infected elderberry plants $(\mathrm{n}=12)$ & and non-infected plants $(\mathrm{n}=4)$ \\
were subjected to a t-test. & Means followed by similar letters are not significantly \\
different $(P \leq 0.05)$. Mean separation within columns by Satterthwaite test when \\
variances were unequal, or with a pooled test when variances were equal. Rust-infected \\
plants averaged 2.6 pustules/plant.
\end{tabular}

Natural rust infection of 'Wyldewood' elderberry canes at a commercial elderberry planting. Ranges of pustule numbers per cane for low, medium, and high infection levels were 10 - 99, 100 - 199, and 200 - 300, respectively, on 31 May 2016. Although pustule number varied, significant differences in vegetative and fruiting were not found among the three levels of rust infection. When data were pooled from rustinfected canes, the mean number of pustules was 137 pustules on 31 May 2016. Rust pustules were also observed on flower pedicels before bloom through harvest on 'Wyldewood' elderberry canes in the field planting (Figs. 2 and 3). Leaf numbers per cane were similar for all plants on 31 May (Table 7). Rust-infected canes averaged 8 cymes/cane and non-infected canes averaged 9 cymes/cane. First and last fruit harvest dates for rust-infected canes were earlier than those for uninfected canes. Berry number and berry yield were reduced by rust infection; however, mean berry weights were similar among all canes. On 26 Aug. 2016, rust-infected plants had two fewer leaves and had $\approx 28 \mathrm{~g}$ less dry weight than uninfected plants, but results were not statistically significant. 
When berry puree was evaluated, soluble solids and $\mathrm{pH}$ were similar among canes, but berry puree from rust-infected canes was $0.8^{\circ}$ Brix lower than that from uninfected plants. Titratable acidity of juice from rust-infected plants was lower than that of puree from uninfected plants.

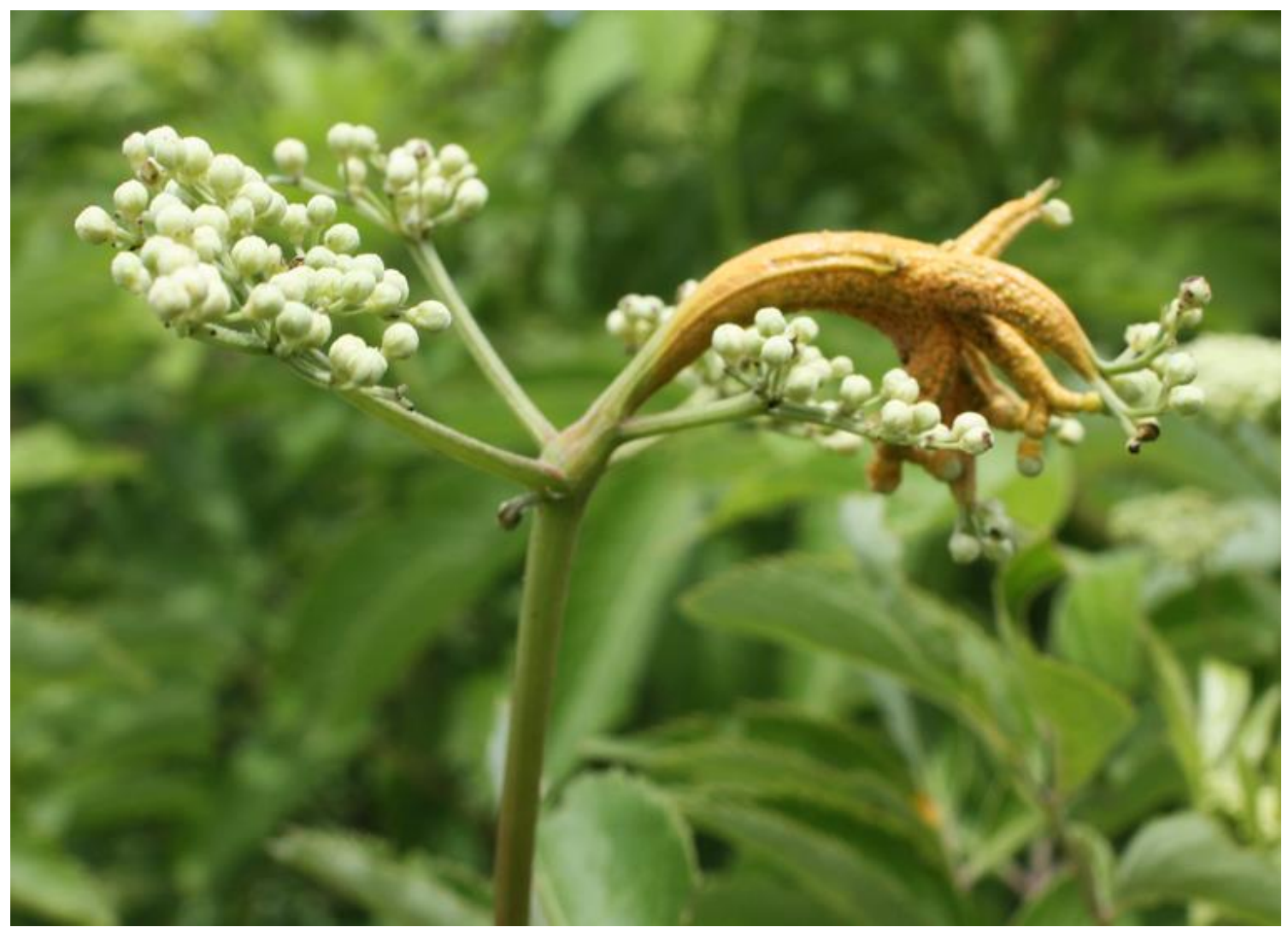

Fig. 2. Rust pustules on 'Wyldewood' elderberry pedicels before bloom. 


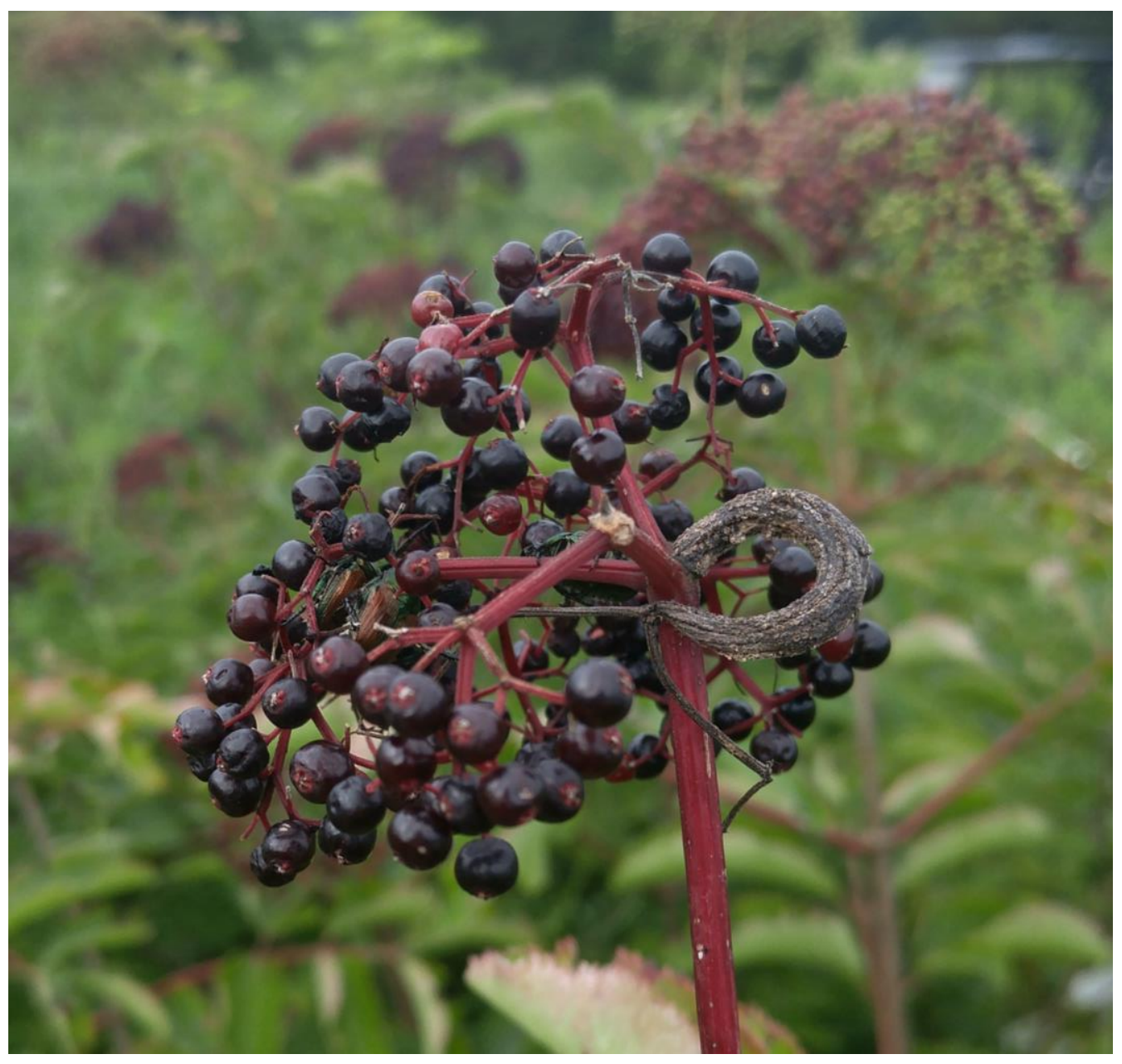

Fig. 3. Rust pustules on 'Wyldewood' elderberry pedicels during harvest. 
Table 7. Vegetative and fruiting characteristics of 'Wyldewood' canes with and without $P$. sambuci rust infection. ${ }^{\mathrm{Z}}$

\begin{tabular}{|c|c|c|c|c|c|c|c|c|}
\hline Treatment & Leaf no. ${ }^{\mathrm{y}}$ & $\begin{array}{c}\text { First harvest } \\
\text { date }^{\mathrm{x}}\end{array}$ & $\begin{array}{c}\text { Last } \\
\text { harvest } \\
\text { date }^{\mathrm{x}}\end{array}$ & Berry no. & $\begin{array}{c}\text { Berry } \\
\text { yield (g) }\end{array}$ & $\begin{array}{c}\text { Mean berry wt. } \\
(\mathrm{mg})\end{array}$ & $\begin{array}{l}\text { Leaf } \\
\text { no. }^{\text {w }}\end{array}$ & $\begin{array}{l}\text { Shoot dry wt. } \\
(\mathrm{g})^{\mathrm{v}}\end{array}$ \\
\hline Rust-infected & $56 \mathrm{a}$ & $217 \mathrm{a}$ & $225 \mathrm{a}$ & $1118 \mathrm{a}$ & $47 \mathrm{a}$ & $43.2 \mathrm{a}$ & $37 \mathrm{a}$ & $58.4 \mathrm{a}$ \\
\hline Uninfected & $49 \mathrm{a}$ & $222 \mathrm{~b}$ & $228 \mathrm{~b}$ & $2105 \mathrm{~b}$ & $88 \mathrm{~b}$ & $40.8 \mathrm{a}$ & $39 \mathrm{a}$ & $86.3 \mathrm{a}$ \\
\hline
\end{tabular}

${ }^{\mathrm{z}}$ Pooled data from rust-infected elderberry canes $(\mathrm{n}=33)$ and non-infected canes $(\mathrm{n}=10)$ were subjected to a t-test. Means followed by different letters are significantly different $(P \leq 0.05)$. Mean separation within columns by Satterthwaite test when variances were unequal, or with a pooled test when variances were equal. Rust-infected canes averaged 137 pustules/cane.

${ }^{y}$ Number of leaves/cane on 31 May 2016.

${ }^{\mathrm{x}}$ Values represent Julian days.

${ }^{w}$ Number of leaves/canes on 26 Aug. 2016.

v'Shoots harvested $10 \mathrm{~cm}$ above media surface on 13 Oct. 2016. 
Table 8. Mean soluble solids, $\mathrm{pH}$, and titratable acidity of berry puree from 'Wyldewood' elderberry canes with or without $P$. sambuci rust infection. ${ }^{\mathrm{Z}}$

\begin{tabular}{lccc}
\hline & $\begin{array}{c}\text { Soluble solids } \\
\text { Treatment }\end{array}$ & $\mathrm{pH}$ & $\begin{array}{c}\text { Titratable acidity } \\
(\mathrm{g} / 100 \mathrm{~mL} \text { as citric acid })\end{array}$ \\
\hline Rust-infected & $10.9 \mathrm{a}$ & $4.5 \mathrm{a}$ & $0.68 \mathrm{a}$ \\
Uninfected & $11.7 \mathrm{a}$ & $4.4 \mathrm{a}$ & $0.78 \mathrm{~b}$ \\
\hline 2 Pooled data from rust-infected elderberry canes $(\mathrm{n}=33)$ & and non-infected canes $(\mathrm{n}=10)$ \\
were subjected to a t-test. Means followed by different letters are significantly different \\
$(P \leq 0.05)$. Mean separation within columns by Satterthwaite test when variances were \\
unequal, and pooled test when variances were equal. Rust-infected canes averaged 137 \\
pustules/cane.
\end{tabular}

\section{DISCUSSION}

Foliar symptoms of Puccinia sambuci rust (i.e., pustules) were first observed on 'Bob Gordon' elderberry plants as early as 5 April (Table 1). In a commercial planting, many rust pustules were observed later (29 May) on foliage and stems of 'Wyldewood' elderberry, with the initial infection occurring earlier. In some cases, stem distortion occurred when numerous rust pustules were present and may have limited cyme development. The number of pustules on leaflets and stems for each cane or plant were summed in these studies, but severity of stem distortion was not evaluated. Rust pustules were also observed on flower pedicels before bloom through harvest on 'Wyldewood' elderberry canes in the field planting (Figs. 2 and 3). Rust infection on pedicels has not been previously reported and likely contributes to loss of flowers and subsequent fruit loss.

Rust infection from $P$. sambuci occurs when germinated basidiospores from sedge plants penetrate susceptible elderberry tissue under favorable environmental conditions, including high humidity or adequate moisture on the plant tissue for a long enough time over a suitable range of temperatures. For the initial rust infection observed on 5 Apr., 
there were five potential infection periods (Table 1). Temperatures during these periods ranged from 10.9 to $13.2^{\circ} \mathrm{C}$ and leaf wetness durations ranged from 3 to $18 \mathrm{~h}$. Of these potential infection periods, conditions occurring on 12 Mar. to 13 Mar. may have resulted in significant pustule development since $5.6 \mathrm{~mm}$ of precipitation occurred with $18 \mathrm{~h}$ of leaf wetness and mean hourly temperature was $13.2^{\circ} \mathrm{C}$.

Number of plants infected and number of pustules (both pycnia and aecia) increased throughout April and May. From 6 Apr. to 27 Apr., there were 14 potential infection periods with five of them occurring during precipitation events. Conditions during 18 Apr. to 19 Apr. may have resulted in significant infection since $58.7 \mathrm{~mm}$ of precipitation occurred with $16 \mathrm{~h}$ of leaf wetness and mean hourly temperature was $16.2^{\circ}$ C. From 29 Apr. to 19 May, 50 more pustules were recorded on elderberry plants when evaluated on 19 May, indicating that additional infection may have occurred at hourly temperatures as high as $17.8^{\circ} \mathrm{C}$. Based on the results of the study, P. sambuci infection on elderberry plants can occur at temperatures between 9 and $18^{\circ} \mathrm{C}$ with adequate relative humidity and moisture. On other plants, such as asparagus, pycnia and aecia of Puccinia asparagi can develop on stems with at least $3 \mathrm{~h}$ of continuous wetting with temperatures ranging from 10 to $30^{\circ} \mathrm{C}$ (Beraha et al., 1960). Maximum infection intensity of $P$. asparagi aecia occurred when mean temperatures remained between 19 and $22^{\circ} \mathrm{C}$ for several days (Beraha et al., 1960). Both P. sambuci and P. asparagi occur during early spring, however the similarity between these fungal species is unknown and has not been investigated.

Few P. sambuci pustules were observed when 'Ozark' elderberry plants were inoculated and incubated at $17^{\circ} \mathrm{C}$ for $48 \mathrm{~h}$. The reason for low pustule numbers may be 
due to few teliospores on sedge leaves, poor teliospore and basidiospore germination, leaf age, or the presence of a thick cuticle on elderberry leaves at the time of infection. French and Lightfield (1990) reported teliospore germination of $P$. punctiformis (Strauss) on Canadian thistle (Cirsium arvense L.) was significantly affected by temperature with maximum germination at 16 to $20^{\circ} \mathrm{C}$. Similarly, Morin et al. (1992) reported that teliospore germination and subsequent $P$. xanthii (Schwein) basidiospore production occurred at $20^{\circ} \mathrm{C}$. After 3 to $6 \mathrm{~h}, P$. xanthii basidiospores germinated at 16 to $28^{\circ} \mathrm{C}$ and produced thin germ tubes which directly penetrated through the cuticle and epidermis of cocklebur (Xanthium occidentale Bertol.) leaves (Morin et al., 1992). In the present study, incubation temperature of inoculated 'Ozark' elderberry plants was $17^{\circ} \mathrm{C}$, which may be near the minimum temperature for teliospore and basidiospore germination. Melander and Craigie (1927) reported that thick epidermal cell walls of barberry (Berberis vulgaris L.) leaves reduced basidiospore penetration from $P$. graminis $\mathrm{f}$. $\mathrm{sp}$. tritici Pers. Thus, the mature middle leaflets inoculated on 'Ozark' elderberry plants may have had thicker epidermal cells that limited basidiospore germ tube penetration. Low humidity or lack of moisture was not likely a limiting factor to $P$. sambuci infection on 'Ozark' plants during incubation as Warmund (2015) achieved high pustule numbers (> 690 pustules/plant) using a similar procedure in which elderberry plants were misted with water before smearing infected sedge leaves on host leaflets and then incubating inoculated plants in bags at $18^{\circ} \mathrm{C}$ for $48 \mathrm{~h}$. Thus, low spore numbers or thickness of the cuticle of mature 'Ozark' leaflets may have the limited basidiospore germ tube penetration into elderberry leaflets. 
Elderberry plant proximity to the alternate host plants also influenced the incidence of rust infection, with those located closest to the sedge developing more pustules. These results suggest that rust infection can be reduced by elimination of the alternate host within or nearby elderberry plants. However, because Carex species have rhizomes, eradication by mechanical means is difficult (Hilty, 2016).

Results from my studies indicate that the effect of $P$. sambuci on vegetative growth of elderberry plants varies with pustule numbers. At low levels of infection $(\leq 6$ pustules/plant), leaf number on 'Bob Gordon' and 'Ozark' was not affected by $P$. sambuci (Tables 3 and 5). However, 'Bob Gordon' elderberry plants had more leaves early in the growing season and may have been more vigorous plants than the controls at the time of infection, resulting in infected plants with higher shoot weight on 10 Oct. (Table 3). Alternatively, a mean infection of six pustules per plant may not have been great enough to reduce shoot dry weight (Table 3). When leaf numbers of inoculated and non-inoculated 'Ozark' plants were nearly the same early in the growing season (19 May), rust-infected plants had 19 fewer leaves on 19 Aug. and 2 g less shoot dry weight on 10 Oct. (Table 5).

When the number of leaves per cane were evaluated on 'Wyldewood' plants, no statistical differences were detected among rust-infected $(\overline{\mathrm{x}}=137$ pustules/cane $)$ and uninfected canes on 31 May or 26 Aug.). Rust-infected canes of 'Wyldewood' elderberry plants had seven more leaves than controls when evaluated on 31 May, but rust-infected plants had two less leaves than the control on 26 Aug. Thus, rust-infected canes lost nearly twice as many leaves (19) compared with uninfected canes (10) by the end of the growing season, indicating that rust enhanced premature defoliation on plants 
(Table 7). Rust-infected canes also had $\approx 28 \mathrm{~g}$ less shoot dry weight than controls on 13 Oct. (Table 7). Because shoot dry weights were limited to tissue removal at $10 \mathrm{~cm}$ above the potting medium surface and plants varied in the number of stems, statistical differences among rust-infected and uninfected plants may not have been detected. In an earlier study, Warmund (2015) found that plant dry weight of 'Bob Gordon' elderberry was reduced when pustule numbers averaged 690 pustules/plant.

The fruiting response of elderberry plants also varied by the level of rust infection. When pustule numbers were low $(\leq 2.6$ pustules/plant $)$, berry numbers and yield were not significantly different among rust-infected and control plants (Table 5). 'Ozark' plants used in this experiment were young (less than two-years-old) and canes were pruned in spring 2016, which may explain the variation in harvested berries. For 'Bob Gordon' plants averaging six pustules/plant, there was a 31\% reduction in berry yield. 'Wyldewood' canes averaging 137 pustules/cane had 47\% fewer berries and total fruit weight at harvest (Table 7). Using a typical plant spacing at $1.2 \times 3.1 \mathrm{~m}(2,688$ plants/ha), berry yields reported herein, and a selling price of $\$ 4.40 / \mathrm{kg}$ fruit (M.

Warmund, personal communication), the estimated loss of income due to rust infection is \$440/ha for 'Bob Gordon' and \$2,295/ha for 'Wyldewood' (assuming 5 canes/plant with similar berry weight).

Soluble solid contents of berry puree from elderberry plants were not statistically different in any of the 2016 experiments. However, soluble solid contents of puree from rust-infected plants was generally 0.6 to $0.9^{\circ}$ Brix lower than that of puree from control plants (Tables 4, 6, and 8). Due to the naturally low soluble solids content of elderberry fruit, sweeteners are added during processing (Warmund et al., 2016). Thus, reduced 
soluble solids in fruit harvested from rust-infected plants would require additional sweetening, therefore increasing the cost of production of processed elderberry products. Titratable acidity was not statistically different between rust-infected and control 'Bob Gordon' and 'Ozark' plants. However, titratable acidity of berry puree from rust-infected 'Wyldewood' canes was $0.11 \mathrm{~g} / \mathrm{mL}$ greater than that of puree from uninfected control canes, indicating that puree quality was adversely affected at a high level of rust infection (Table 8). 


\section{LITERATURE CITED}

Agrios, G.N. 2005. Plant pathol. $5^{\text {th }}$ ed. Elsevier Academic Press, Burlington, Mass.

Arthur, J.C. 1962. Manual of the rusts in the United States and Canada. Hafner

Publishing, New York.

Beraha, L., M.B. Linn, and H.W. Anderson. 1960. Development of the asparagus rust pathogen in relation to temperature and moisture. Plant Dis. Rptr. 44:82-86.

Bolley, H.L. 1889. The heteroecismal Pucciniae. The Amer. Monthly Microsc. J. 8:169180.

French, R.C. and A.R. Lightfield. 1990. Induction of systemic aecial infection in Canada thistle (Cirsium arvense) by teliospores of Puccinia punctiformis. Pytopathology 80:872-977.

Kellerman, W.A. 1904. Uredineous infection experiments in 1904. J. of Mycol. 11:26-33.

Littlefield, L.J. and M.C. Heath. 1979. Ultrastructure of rust fungi. Academic Press, New York.

Hilty, J. 2016. Frank’s Sedge. Illinois Wildflowers. 3 Oct. 2016. <http://www.illinoiswildflowers.info/grasses/plants/frank_sedge.htm>.

Mims, C.W. 1981. SEM of aeciospore formation in Puccinia sambuci. Scanning Electron Miscrosc. 3:299-303.

Melander, L.W. and J.H. Craigie. 1927. The nature of resistance of Berberis spp. to Puccinia graminis. Phytopathology 17:96-114.

Morin, L., J.F. Brown, and B.A. Auld. 1992. Effects of environmental factors on teliospore germination, basidiospore formation, and infection of Xanthium occidentale by Puccinia xanthii. Ecol. and Epidemiology. 82:1443-1447.

Petersen, R. 1974. The rust fungus life cycle. Botanical Rev. 40:453-513. 
Saccardo, P.A. 1891. Sylloge fungorum omnium hucusque cognitorum. R. Friedlander and Sohn, Berlin.

Warmund, M. 2015. Elderberry rust: a conspicuous disease of Sambucus. HortScience 50:S182 (abstr.).

Warmund, M., M. Kwasniewski, J. Elmore, A. Thomas, and K. Adhikari. 2016. Sensory attributes of juice from North American-grown elderberry cultivars. HortScience $51: 1561-1565$. 


\section{CHAPTER 3: ELDERBERRY LEAF SPOT STUDY}

\section{INTRODUCTION}

In Missouri, leaf spot lesions on elderberry are generally observed in the summer when temperatures are warm and relative humidity is high. Several leaf spot diseases have been reported for elderberry and their causal agents including, Ascochyta wisconsina Davis, Phaeoramularia catenospora Atk., Cercospora depazeoides Desm., Cerosporella prolificans Ellis \& Holw., Phyllosticta sambuci Desm., Mycosphaerella sp., Ramularia sambucina Sacc., and Septoria sambucina Peck. (Charlebois et al., 2010). However, since elderberry is a relatively new specialty crop, few of these organisms have been identified in Missouri.

Colletotrichum is an important genus of plant pathogenic fungi that parasitize sagricultural crops worldwide such as, cereals and grasses, cucurbits, eggplant, tomato, strawberry, sugarcane, mango, avocado, olive, coffee, etc. (Agrios, 2005). Based upon economic importance, Colletotrichum species are considered the eighth most injurious plant pathogenic fungi in the world (Cannon et al., 2012). Anthracnose, a common disease associated with Colletotrichum, appears as blackened sunken necrotic lesions caused by black acervuli on stems, leaves, and fruit (Freeman et al., 1998). Colletotrichum symptoms including leaf spots have been reported on hosts, such as American sweetgum (Garibaldi et al., 2016), walnut (Zhu et al., 2015), orange (Cheng et al., 2014), and apple (Crusius et al., 2002).

Infection and disease development of Colletotrichum is promoted by warm, wet, and humid conditions (Coates et al., 2014). Colletotrichum species produce asexual conidia which are disseminated by splash from frequent precipitation, irrigation, or heavy 
dews, especially when plants are overcrowded (Than et al., 2008). Colletotrichum can also be disseminated by the introduction of infected transplants (Hyde et al., 2009; Cannon et al., 2012). The duration of surface leaf wetness has the greatest influence on conidial germination, infection, and growth of Colletotrichum within the host (Than et al., 2008). Conidia germinate on susceptible host tissue and form an infection structure called an appressoria which mechanically penetrates host plant epidermal walls and releases compounds, such as glycerol and melanin that aide in increasing turgor pressure for penetration (Agrios 2005; Kubu et al., 2000). Initially, Colletotrichum infection begins a biotrophic nutrition strategy, however, a delayed necrotrophic nutrition strategy follows resulting in death of plant cells and pathogenic lesions (O'Connell et al., 2000; Perfect et al., 1999). The production of host-induced virulence effectors promotes the growth of the fungus within plant tissues (Cannon et al., 2012).

Symptoms appear several days to weeks after infection as Colletotrichum species have a latent period which is temperature dependent with higher temperatures resulting in shorter latent periods (King et al., 1997). Yakoby et al. (2000) reported that $C$.

gloeosporioides Penz. secreted ammonia in host tissue, which resulted in a $\mathrm{pH}$ increase in the infected area and enabled production of pectate lyase, a cell wall-degrading enzyme which promotes fungal pathogenicity. C. acutatum J.H. Simmonds in apple and $C$. coccodes Wallr. in tomato also produced ammonia and increased $\mathrm{pH}$ in the infected tissue, resulting in maceration of plant cell walls and enhanced virulence (Prusky et al., 2001). Acervuli develop on lesions on infected plant tissues and produce additional conidia, causing secondary infection of additional plants throughout the growing season (Coates et al., 2014). 
Colletotrichum species survive and overwinter by producing micro-sclerotia in and on dead host tissues of crop residues and seeds (Than et al., 2008). Some Colletotrichum species produce a Glomerella telemorph (i.e., sexual stage) which most often develops on dead host tissues (Cannon et al., 2012). The disease cycle of Colletotrichum will repeat under favorable environmental conditions during the following growing season with the production of conidia or ascospores if a Glomerella telemorph is present.

The systematics of Colletotrichum species are considered unsatisfactory due to discrepancies in morphological distinctions among species, as well as ambiguity of species lifestyles, and incorrectly-named sequences in GenBank (Hyde et al., 2009). Symptoms from Colletotrichum species observed on plant material and in culture vary widely in morphological features and vary with environmental conditions, making morphology based identification especially difficult (Cannon et al., 2012).

C. acutatum has been reported on elderberry (Sambucus nigra) fruit, but no other plant organs in Switzerland (Michel et al., 2013). In 2015, Colletotrichum was isolated from necrotic lesions on elderberry leaflets from 'Bob Gordon' elderberry in Missouri (J.D. Mihail, unpublished data). Therefore, the objectives of this study were to document Colletotrichum species infecting American elderberry in Missouri and determine which species are associated with elderberry leaf spot.

\section{MATERIALS AND METHODS}

Fungal isolations from leaf spots on elderberry plants. Fungi were isolated from symptomatic leaf spots occurring on two-year-old 'Bob Gordon' elderberry plants 
growing in containers $(3.74 \mathrm{~L})$ in a nursery area at the Horticulture and Agroforestry Research Center (HARC) on 7 June 2015. Leaf spots were angular, purple-colored lesions with necrotic centers. Each lesion was cut from a leaflet $(\approx 5 \mathrm{~mm} \times 5 \mathrm{~mm})$, containing both the diseased tissue and a surrounding margin of green tissue. Infected tissues were then surface sterilized in $70 \%$ ethanol for 30 to $45 \mathrm{~s}$ and rinsed twice for $30 \mathrm{~s}$ in sterile deionized water. Lesions were blotted dry with a sterile paper towel, cut in half, and both pieces of tissue were placed in 60-mm-diameter petri dishes (Fisher Scientific, Hanover Park, IL) with half-strength potato dextrose agar (PDA). The medium was prepared by dissolving $19.5 \mathrm{~g}$ potato dextrose agar (Remel, Thermo Fisher Scientific, Lenexa, $\mathrm{KS}$ ) in $1 \mathrm{~L}$ deionized water supplemented with $0.5 \mathrm{~g}$ streptomycin sulfate (Sigma Chemical Co, St. Louis, MO) to exclude bacteria. Plates were then incubated for 2 to $3 \mathrm{~d}$ in an inverted position at $\approx 23^{\circ} \mathrm{C}$ under fluorescent lighting $\left(75 \mu \mathrm{mol} \cdot \mathrm{m}^{-2} \cdot \mathrm{s}^{-1}\right)$ with a $10 \mathrm{~h}$ photoperiod until hyphal growth was $\approx 3 \mathrm{~mm}$ from the diseased tissue. Hyphae were then transferred from the cultures and plated in Van Tieghem cells (Tuite, 1969) in 60-mm-diameter petri dishes containing water agar streptomycin (WAS) media. WAS media was prepared by dissolving $20 \mathrm{~g}$ technical agar (Difco ${ }^{\mathrm{TM}}$, Becton, Dickinson and Company, Sparks MD), in $1 \mathrm{~L}$ deionized water, with $0.5 \mathrm{~g}$ streptomycin sulfate. After hyphae had grown $3 \mathrm{~mm}$ from the Van Tieghem cell, they were transferred and plated in 95-mm-diameter petri dishes containing half-strength PDA as previously described.

Fungal isolates were maintained in pure culture on half-strength PDA at $\approx 23^{\circ} \mathrm{C}$ under fluorescent lighting $\left(75 \mu \mathrm{mol} \cdot \mathrm{m}^{-2} \cdot \mathrm{s}^{-1}\right)$ with a $10 \mathrm{~h}$ photoperiod. On $1 \mathrm{Feb} .2016$, isolates were sent to the University of Missouri Plant Diagnostic Clinic for DNA 
sequencing. Actively growing mycelium were cultured on full-strength PDA (39 g potato dextrose agar and $1 \mathrm{~L}$ deionized water) plates covered with cellophane and, mycelia were scraped from the cellophane were then frozen at $-80^{\circ} \mathrm{C}$. Genomic DNA was extracted using the Easy-DNA kit (Invitrogen Corp., Carlsbad, CA) from the frozen mycelia. The internal transcribed spacer (ITS) region was amplified with PCR using primer pairs ITS5 (5' -GAAGTAAAAGTCGTAACAAGG -3') (Ristanio et al., 1998) and ITS4 (5' -TCCTCCGCTTATTGATATGC -3') (Gardes and Burns, 1993). Each PCR consisted of $10 \mu \mathrm{L}$ of MyTaq red reaction buffer (Bioline Inc., Taunton, MA), 200 $\mathrm{nM}$ of each primer, $0.25 \mu \mathrm{L}$ of Taq polymerase (Bioline Inc.), and $50 \mathrm{ng}$ of genomic DNA (Cottrill et al., 2016). Thermal cycling conditions involved initial denaturation at $95^{\circ} \mathrm{C}$ for $10 \mathrm{~min}$ followed by 40 cycles of $95^{\circ} \mathrm{C}$ for $30 \mathrm{~s}, 50^{\circ} \mathrm{C}$ for $30 \mathrm{~s}$, and $72^{\circ} \mathrm{C}$ for 1 min, and a final extension step at $72^{\circ} \mathrm{C}$ for $10 \mathrm{~min}$. Purification of amplified isolated DNA was performed using the ExoSAP-IT kit (Thermo Fisher Scientific, Lenexa, KS). Purified PCR products were Sanger-sequenced by the University of Missouri DNA sequencing facility. Base calls were checked manually and reads assembled in SeqMan Pro (DNASTAR Inc., Madison, WI). The assembled contig was subjected to BLAST analysis against the National Center for Biotechnology Information nucleotide database (Sharma et al., 2014) and isolates were putatively identified as Colletotrichum. Colletotritchum cultures were sent by overnight mail to the USDA ARS Systematic Mycology \& Microbiology Lab in Beltsville, MD on 9 Feb. 2016 for DNA analysis by amplifying ITS regions to determine the species. Putative results indicated that the culture was Colletotrichum salicis. 
On 20 Nov. 2015, elderberry plants were covered with a polyethylene foam blanket and plastic sheeting for winter protection. Plants were uncovered on 11 Mar. 2016. Dormant oil (Damoil®; Drexel Chemical Company, Memphis, TN) was applied to plants to control overwintering eriophyid mites (Phyllocoptes wisconsinensis Kiefer) at $7.5 \mathrm{~mL}$ a.i. $\cdot \mathrm{L}^{-1}$ on 14 Mar. 2016. Elderberry plants were fertilized with $50 \mathrm{~g} 15 \mathrm{~N}-9 \mathrm{P}-12 \mathrm{~K}$ controlled-release fertilizer (Osmocote®; Scotts Company, Marysville, OH) on 21 Mar. 2016 and pruned to six nodes on 28 Mar. 2016. From 22 Mar to 25 Jul. 2016, spirodiclofen (Envidor® 2 SC; Bayer, Research Triangle Park, NC) was applied at 240 $\mathrm{g} / \mathrm{L}$ a.i. at 10 to $14 \mathrm{~d}$ intervals for mite control.

Inoculation of 'Bob Gordon' elderberry plants with Colletotrichum. Forty-eight C. salicis sub-cultures were prepared on 16 May 2016 using Czapek-Dox V8 agar (CDV8). CDV8 media was prepared by dissolving $45.4 \mathrm{~g}$ Czapek agar (Difco ${ }^{\mathrm{TM}}$, Becton, Dickinson and Company, Sparks, MD) and $10 \mathrm{~g}$ technical agar with $200 \mathrm{~mL}$ clarified V8 (Campbell Soup Company, Camden, NJ) and $800 \mathrm{~mL}$ deionized water. Petri dishes were then inverted and placed at $\approx 23^{\circ} \mathrm{C}$ under fluorescent lighting $\left(75 \mu \mathrm{mol} \cdot \mathrm{m}^{-2} \cdot \mathrm{s}^{-1}\right)$ with a $10 \mathrm{~h}$ photoperiod.

Three concentrations of $C$. salicis inoculum were prepared from the plates. Conidia were retrieved by flooding each plate with $15 \mathrm{~mL}$ of sterile deionized water for 10 min, gently agitating the culture with a sterile bent glass rod, and then pipetting the suspended spore solution into a sterile beaker. Concentrations were determined and adjusted using a hemacytometer (Fisher Scientific, Hanover Park, IL). Low, medium, and high conidial concentrations were $1.67 \times 10^{3}, 5.0 \times 10^{4}$, and $5.0 \times 10^{5}$ conidia $\cdot \mathrm{mL}^{-1}$, respectively. 
Immediately before plant inoculation, $\approx 22 \mu \mathrm{L}$ surfactant (Tween 20; Croda Inc., New Castle, DL) was added to each conidial solution and an aerosol pressurized sprayer (Sigma-Aldrich, St. Louis, MO) was used to apply $30 \mathrm{~mL}$ of inoculum onto each elderberry plant on 9 Jun. 2016. Eight plants were inoculated at each concentration of conidia and eight plants were used as non-infected controls. Immediately after inoculation, $C$. salicis treated and non-treated elderberry plants were placed on an inverted 8.5 L polyethylene container and sealed in $208 \mathrm{~L}$ polyethylene bags containing $10 \mathrm{~L}$ of water to maintain a humid environment for conidial germination and infection. Bagged plants were incubated at $26^{\circ} \mathrm{C}$ for $36 \mathrm{~h}$. After incubation, plants were arranged in a randomized complete block design in the nursery area at HARC. Sixteen 'Ozark' elderberry plants were interspersed among the 'Bob Gordon' plants for pollination. Overhead irrigation was used to irrigate throughout the growing season.

Pathogenicity and re-isolation. Two leaflets exhibiting leaf spot symptoms were sampled from each of the inoculated plants and photographed on 28 Jun. 2016. Fungal isolations were performed as previously described to achieve pure cultures. On 25 July 2016, the number of symptomatic leaf spots per plant were recorded for all elderberry plants. Two leaflets per plant were collected and two lesions from each leaflet were used for the re-isolation process as previously described. All the re-isolated cultures were kept in the dark at $\approx 23^{\circ} \mathrm{C}$ and monitored for conidial production. Cultures plated on halfstrength PDA from the 25 Jul. 2016 isolation exhibiting Colletotritchum conidia were sent by overnight mail to the USDA ARS Systematic Mycology \& Microbiology Lab in Beltsville, MD on 29 Aug. 2016 for DNA analysis by amplifying ITS regions to determine the genus and species. 


\section{RESULTS}

Leaf spot identification. One inoculated and two control plants were lost during this study due to an irrigation system malfunction. Nineteen days after inoculation of $C$. salicis isolates, leaf spot symptoms were observed on nine of the inoculated plants. Symptoms were angular, purple-colored leaf spot lesions with necrotic centers (Fig. 4). However, inoculation treatments did not result in varying numbers of symptomatic leaf spots. After re-isolation of fungi from elderberry leaflets, four of nine cultures produced conidia consistent with Colletotrichum as described by Weir et al. (2012). All three inoculation treatments produced Colletotrichum conidia in culture after $20 \mathrm{~d}$ of growing on half-strength PDA. Colony color was light grey with light brown concentric bands and slight shades of salmon and pink towards the center. Conidia were one-celled, hyaline, and cylindrical with round ends when examined with a compound microscope at 30x magnification (Fig. 5). Sclerotia and melanized hyphae were also present on the cultures. Other fungal organisms were isolated from lesions on other infected elderberry plants, but they appeared morphologically dissimilar from the putative Colletotrichum cultures.

On 25 Jul. 2016, 22 of 23 inoculated plants had leaf spot lesions. Five of six control plants also had leaf spot lesions, indicating natural infections occurred. Only one culture from a control plant produced Colletotrichum-like colonies. Fungi from the high inoculation treatment produced conidia during the second re-isolation.

The USDA ARS Systematic Mycology \& Microbiology Lab putatively identified fungi from the inoculated and non-inoculated plants as Colletotrichum kahawae subsp. 
ciggaro (Fig. 6), and Colletotrichum aenigma (Fig. 7), respectively, based on ITS sequencing.

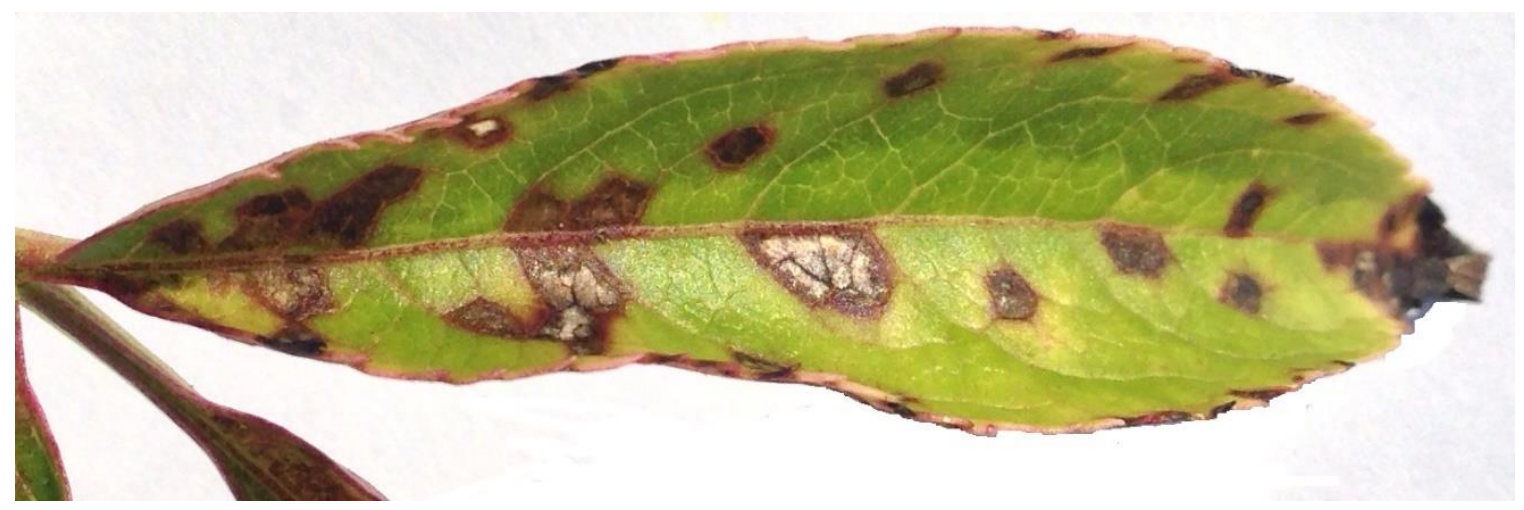

Fig. 4. Colletotrichum lesions on infected elderberry leaflet.

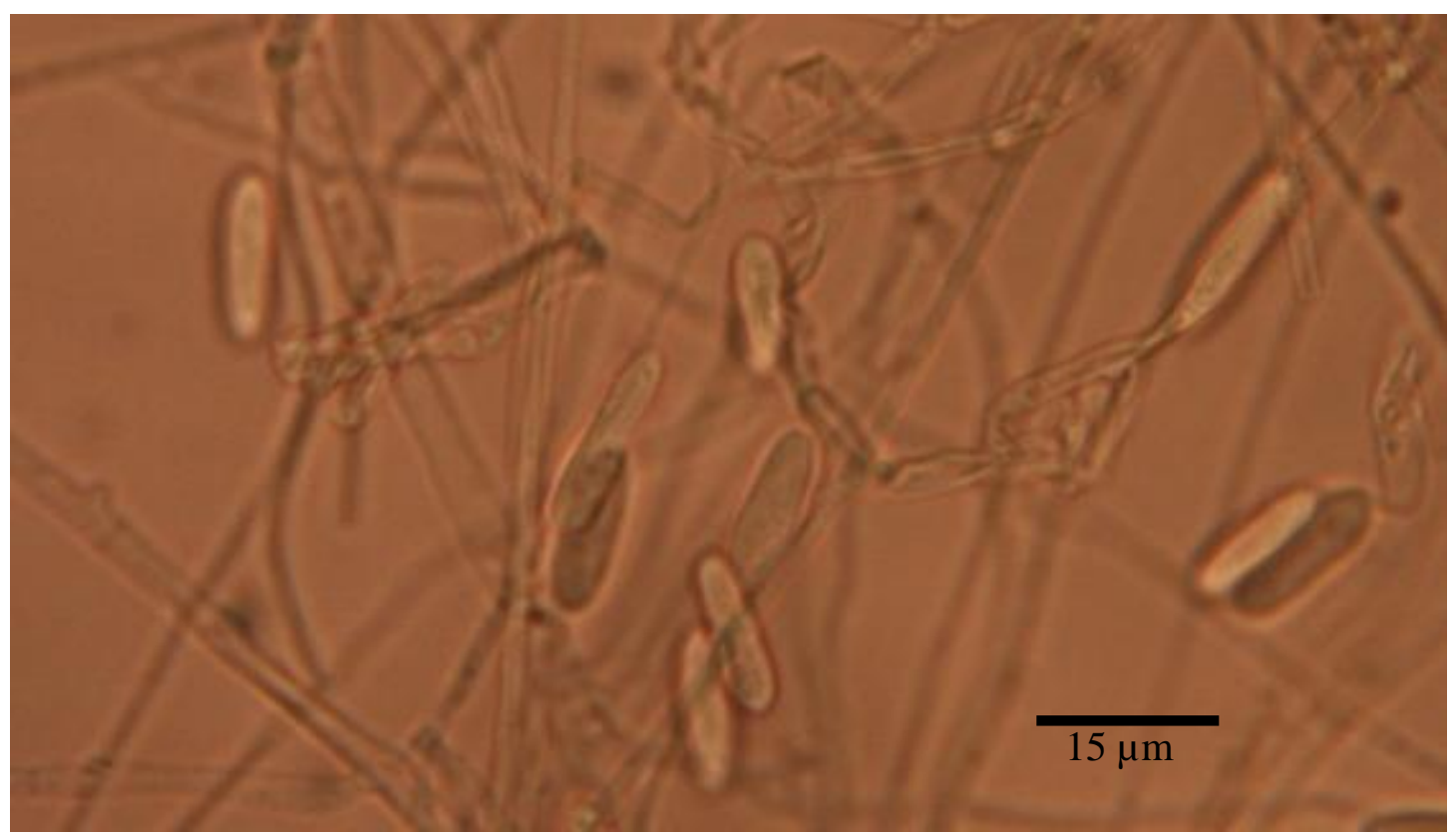

Fig. 5. Colletotrichum conidia spores as seen under the compound microscope. 


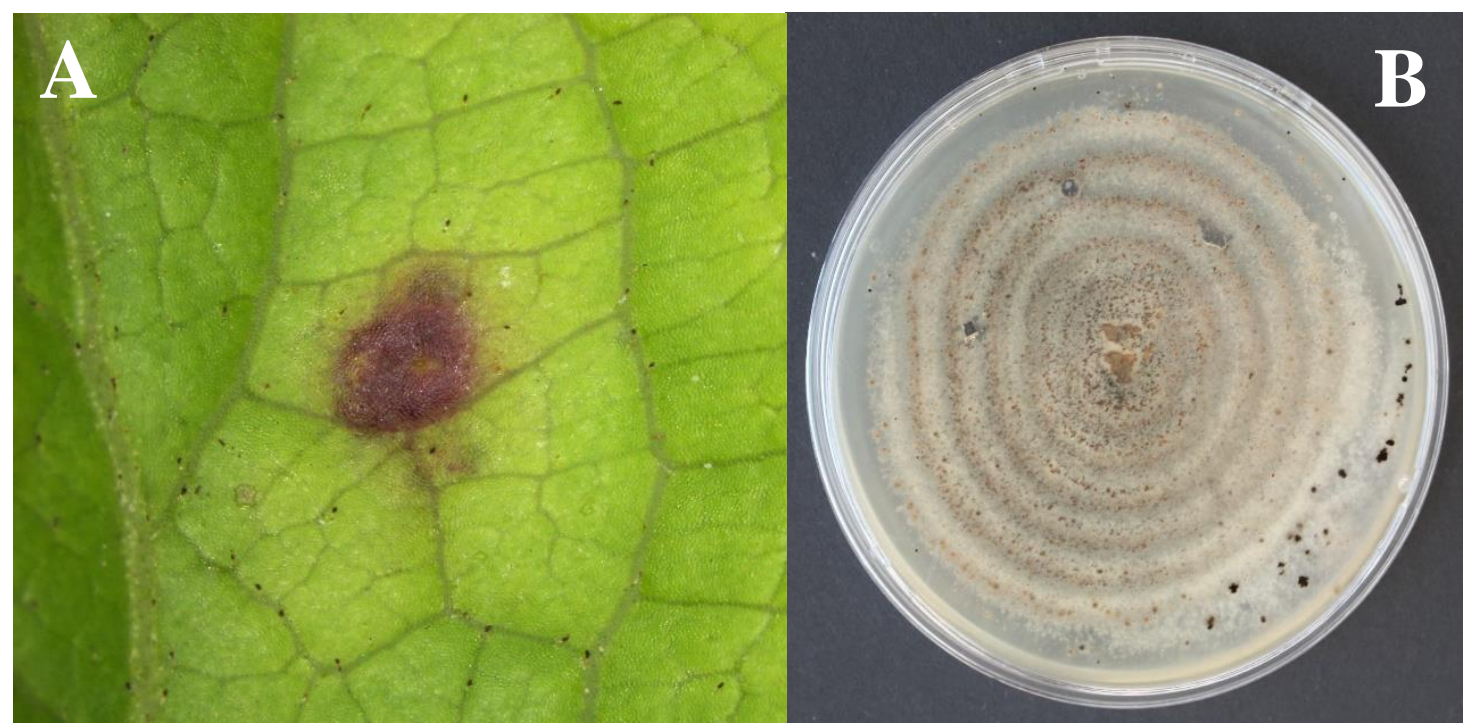

Fig.6. (A) Elderberry foliar symptoms of Colletotrichum kahawae subsp. ciggaro and (B) its colony morphology on half strength potato dextrose agar.

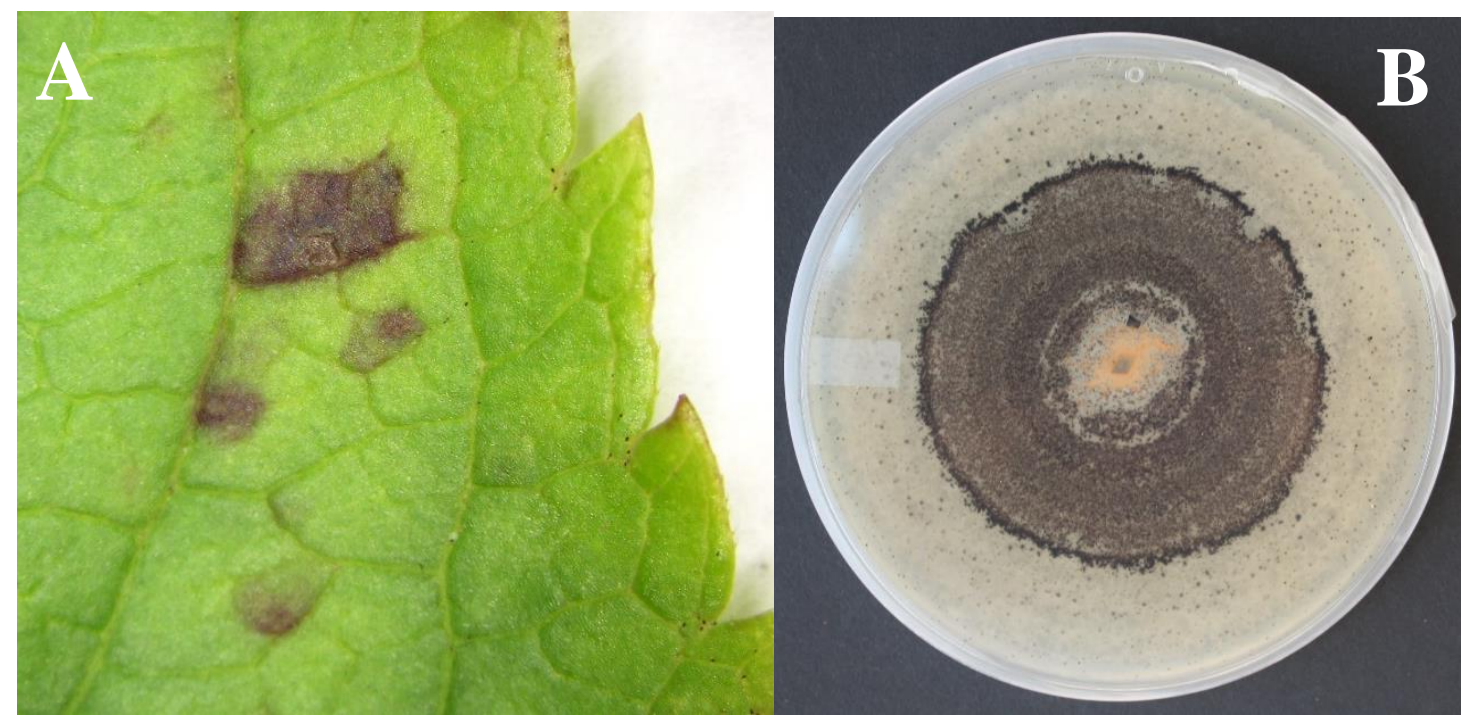

Fig. 7. (A) Elderberry foliar symptoms of Colletotrichum aenigma and (B) its colony morphology on half strength potato dextrose agar.

\section{DISCUSSION}

On 25 Jul. 2016, 22 of 23 inoculated plants had leaf spot lesions. Due to the close proximity of infected plants and control plants in the nursery area, four out of five noninoculated control plants developed leaf spot symptoms during the growing season. 
Three putative fungal pathogens were tentativley identified from leaf spots occurring on elderberry during the 2015 and 2016 growing season including, Colletotrichum salicis, $C$. kahawae subsp. ciggaro, and C. aenigma. Although 'Bob Gordon' elderberry plants were inoculated with $C$. salicis, other Colletotrichum species were re-isolated from leaf spot lesions on infected plants, indicating background infection occurred. Also, the use of daily overhead irrigation likely enhanced disease infection from fungi other than $C$. salicis. Colletotrichum conidia are most often dispersed from acervuli on lesions during warm, wet conditions by rain splashing. Thus, the use of overhead irrigation for elderberry plants likely caused initial and secondary infections to occur on inoculated and non-inoculated plants.

Interestingly, the two Colletotrichum species isolated from leaf spots in 2015 and 2016 vary phylogenetically. $C$. salicis belongs to the acutatum clade and both $C$. kahawae subsp. ciggaro and $C$. aenigma belong to the gloeosporioide clade (Cannon et al., 2012; Weir et al., 2012). All three species of Colletotrichum produced visually-similar lesions on elderberry leaflet tissue, appear similar in colony morphology, and produce visuallysimilar conidia, making it difficult to distinguish the species based upon symptom and isolate morphology. Molecular techniques have been adopted to characterize and identify taxa within Colletotrichum; however, accurate identification of Colletotrichum species has its limitations due to ambiguity of species lifestyles and incorrectly-named sequences in GenBank (Hyde et al., 2009). Therefore, although species of Colletotrichum were sequenced using ITS, it is difficult to classify these species with $100 \%$ certainty due to taxonomic and phylogenetic confusion within the genus. 
C. salicis was first isolated from angular, purple-colored lesions with necrotic centers on elderberry leaflets sampled on 7 June 2015 from two-year-old 'Bob Gordon' elderberry plants. C. salicis has not previously been reported on elderberry. Known hosts of C. salicis include Asian pear (Pyrus pyrifolia Burman), apple (Malus domestica Borkh.), and strawberry (Fragaria x ananassa Dutch.) in New Zealand, and tomato (Solanum lycopersicum L.) in Germany (Damm et al., 2012). Symptoms of this species have been described as fruit rot, anthracnose, and petiole lesions (Damm et al., 2012). Sexual morphs of this species have been identified as Glomerella salicis (Damm et al., 2012; Jayawardena et al., 2016).

In September 2013, C. acutatum was identified as the causal agent of anthracnose on black elderberry (Sambucus nigra L.) fruit in Switzerland (Michel et al., 2013). Isolates of $C$. acutatum from black elderberry grown on potato dextrose agar resulted in the growth of white to grey mycelium with salmon-colored spore masses, similar to the culture morphology of C. salicis, C. kahawae subsp. ciggaro and C. aenigma observed on half strength potato dextrose agar during the 2016 growing season. Small lesions were observed on individual berries grown at the commercial planting in New Bloomfield, Mo in 2016, however attempts at isolating the causal agent were inconclusive.

C. acutatum is one of the most severe diseases on strawberry (Fragaria $\mathrm{x}$ ananassa), resulting in major crop losses (Freeman and Nizani 1997; Leandro et al., 2001). Lesions on petioles and leaves are observed with C. acutatum infection of strawberry, as well as flower blight and fruit rot. Most often, C. acutatum is introduced to strawberry fields by infected plant material and can survive as a symptomless 
endophyte in living strawberry tissue (Cannon et al., 2012; Hyde et al., 2009). It is unknown if Colletotrichum is endophytic in elderberry.

While this is the first report of $C$. kahawae subsp. ciggaro on elderberry, coffee (Coffea Arabica L.) is a commercially-important host for this fungus and is the causal agent of coffee berry disease, which is a major limiting factor of coffee production. The fungus infects green coffee berries, causing anthracnose-like symptoms and premature fruit drop (Pires et al., 2015). Yield losses up to 70 to $80 \%$ can result from infection if no control measures are used (Pires et al., 2015). Other known hosts of $C$. kahawae subsp. ciggaro include blueberry (Vaccinium spp.) and avocado (Persea spp.) (Weir et al., 2012). Sexual morphs have been identified as Glomerella cingulate var. migrans and Glomerella rufomaculans var. vaccinia (Weir et al., 2012).

Colletotrichum aenigma also has not been reported on elderberry. Known hosts of C. aenigma include Asian pear (Pyrus pyrifolia) in Japan, avocado (Persea americana Miller) in Israel (Weir et al., 2012), and dragon fruit (Hylocereus undatus Haw.) in Thailand (Meetum et al., 2015). Symptoms of infection by this species have been described as necrotic lesions on mature stems and fruits (Meetum et al., 2015). Weir et al. (2012), reported C. aenigma may have more white aerial mycelium in culture compared to other species, however this was not the case for colonies isolated in 2016. Although elderberry plants were inoculated with C. salicis and Koch's postulates were not fulfilled, premature defoliation on elderberry plants was observed in the 2016 study (presumably caused by Colletotrichum species). To prevent leaf spot diseases of elderberry, drip irrigation could be used to limit leaf wetness periods conducive to Colletotrichum infection. 


\section{LITERATURE CITED}

Agrios, G.N. 2005. Plant pathol. $5^{\text {th }}$ ed. Elsevier Academic Press, Burlington, Mass.

Cannon, P.F., U. Damm, P.R. Johnson, and B.S. Weir. 2012. Colletotrichum- current status and future directions. Studies in Mycol. 73:181-213.

Charlebois, D., P.L. Byers, C.E. Finn, and A.L Thomas. 2010. Elderberry: botany, horticulture, potential. Hort. Rev. 37:213-280.

Cheng, B.P., Y.H. Huang, A.T. Peng, J.F. Ling, X.B. Song, and X. Chen. 2014. First report of leaf and fruit spots of Citrus reticulate Blanco cv. Nian Ju caused by Colletotrichum truncatum in China. Plant Dis. 98:422.

Coates, L., T. Cooke, and L. Forsberg. 2014. The biology and management of Colletotrichum disease in production nurseries. Agri-science Queensland Dept. of Agr., Fisheries and Ecosciences Precinct, Queensland, Australia. 4 Apr. 2017. $<$ https://www.ngia.com.au/Attachment?Action=Download\&Attachment_id=1829>.

Cottrill, D.J., D.T. Earlywine, and G.L. Miller. 2016. Assessment of nitrogen source, sulfur, and fall fungicide applications on the management of spring dead spot of bermudagrass. Plant Dis. 100:473-482.

Crusius, L.U., C.A. Forcelini, R.M.V. Sanhueza, and J.M.C. Fernandes. 2002. Epidemiology of apple leaf spot. Fitopatol. Bras. 27:65-70.

Damm, U., P.F. Cannon, J.H.C. Woudenberg, and P.W. Crous. 2012. The Colletotrichum acutatum species complex. Studies in Mycol. 73:37-113.

Freeman, S., T. Katan, and E. Shabi. 1998. Characterization of Colletotrichum species responsible for anthracnose diseases of various fruits. Plant Dis. 82:596-605.

Freeman, S., and Y. Nizani. 1997. Control of Colletotrichum acutatum in strawberry under laboratory, greenhouse, and field conditions. Plant Dis. 81:749-752. 
Gardes, M., and T.D. Burns. 1993. ITS primers with enhanced specificity for basidiomycetes - application to the identification of mycorrhizae and rusts. Mol. Ecol. 2:113-118.

Garibaldi, A., G. Gilardi, S. Franco-Ortega, and M.L. Gullino. 2016. First report of leaf spot caused by Colletotrichum kahawae on American sweetgum (Liquidambar styraciflua) in Italy. J. Plant Pathol. 98:370.

Hyde, K. D., L. Cai and E. Mckenzie. 2009. Colletotrichum: a catalogue of confusion. Fungal Diversity 39:1-17.

Jayawardena, R.S., K.D. Hyde, U. Damm, L. Cai, M. Liu, X.H. Li, W. Zhang, W.S. Zhao, and J.Y. Yan. 2016. Notes on currently accepted species of Colletotrichum. Mycosphere 7:1192-1260.

King, W.T., L.V. Madden, M.A. Ellis, and L.L Wilson. 1997. Effect of temperature on sporulation and latent period of Colletotrichum spp. infecting strawberry fruit. Plant Dis. 81:77-84.

Kubu, Y, Y. Takano, G. Tsuji, O. Horino, and I. Furusawa. 2000. Regulation of melanin biosynthesis genes during appressorium formation by Colletotrichum lagenarium, p. 99-113. In: D. Prusky, S. Freeman, and M.B. Dickman (eds.). Colletotrichum: host specificity, pathology, and host-pathogen interaction. APS Press. St. Paul, Minn.

Leandro, L.F.S, M.L. Gleason, F.W. Nutter, S.N. Wegulo, and P.M. Dixon. 2001. Germination and sporulation of Colletotrichum acutatum on symptomless strawberry leaves. Phytopathology 91:659-664. 
Meetum P., C. Leksomboon, and M. Kanjanamaneesathian. 2015. First report of Colletotrichum aenigma and C. siamense, the causal agents of anthracnose disease of dragon fruit in Thailand. J. of Plant Pathol. 97:402.

Michel, V.V., R. Hollenstein, A. Stensvand, and G.M. Stromeng. 2013. Colletotricum acutatum, agent of anthracnose on the new host black elderberry (Sambucus nigra) in Switzerland. Amer. Phytopathol. Soc. 97:1246.

O’Connell, R., S. Perfect, B. Hughes, R. Carzaniga, J. Bailey, and J. Green. 2000. Dissecting the cell biology of Colletotrichum infection processes, p. 57-77. In: D. Prusky, S. Freeman, and M.B. Dickman (eds.). Colletotrichum: host specificity, pathology, and host-pathogen interaction. APS Press. St. Paul, Minn.

Perfect, S.E., H.B. Hughes, R.J. O’Connell, and J.R. Green. 1999. Colletotrichum: a model genus for studies on pathology and fungal-plant interactions. Fungal Genet. and Biol. 27:186-198.

Pires, A.S., H.G. Azinheria, A. Cabral, S. Tavares, D. Tavares, M. Castro, V. Varzea, M.C. Silva, R. Abranches, J. Loureiro, and P. Talhinhas. 2015. Cytogenomic characterization of Colletotrichum kahawae, the causal agent of coffee berry disease, reveals diversity in minichromosome profiles and genome size expansion. Plant Pathol. 65:968-977.

Prusky, D., J.L. McEvoy, B. Leverentz, and W.S. Conway. 2001. Local modulation of host $\mathrm{pH}$ by Colletotrichum species as a mechanism to increase virulence. Mol. Plant-Microbe Interactions 14:1105-1113. 
Ristanio, J.B., M. Madritch, C.L. Trout, and G. Parra. 1998. PCR amplification of ribosomal DNA for species identification in the plant pathogen genus Phytophthora. Appl. Environ. Microbiol. 64:948-954.

Sharma K., E. Goss, A.H.C. van Bruggen. 2014. Isolation and identification of the fungus Colletotrichum cordylinicola causing anthracnose disease on Cordyline fruticose in Florida. HortScience 49:911-916.

Than, P., H. Prihastuti, S. Phoulivong, P.W.J. Taylor, and K.D. Hyde. 2008. Chilli anthracnose disease caused by Colletotrichum species. J. Zhejiang Univ. 9:764778.

Tuite, J. 1969. Plant Pathological Methods. Fungi and Bacteria. Burgess Publishing, Minneapolis, MN.

Weir B. S., P.R. Johnston, and U. Damm. 2012. The Colletotrichum gloeosporioides species complex. Studies in Mycol. 73:115-180.

Yakoby, N., I. Kobiler, A. Dinoor, and D. Prusky. 2000. pH regulation of pectate lyase secretion modulates the attack of Colletotrichu, gloeosporioides on avocado fruits. Appl. and Environ. Microbiology 66:1026-1030.

Zhu, Y.Z., W.J Liao, D.X. Zou, and Y.J. Wu. 2015. First report of leaf spot disease on walnut caused by Colletotrichum fioriniae in China. Plant Dis. 99:289. 


\section{CHAPTER 4: SUMMARY AND CONCLUSIONS}

Four studies were conducted to evaluate the effect of elderberry diseases in Missouri caused by fungal pathogens. In the first study, infection periods of elderberry rust from Puccinia sambuci occurred in early April at 9 to $18^{\circ} \mathrm{C}, \geq 3 \mathrm{~h}$ leaf wetness, and $\geq 85 \%$ relative humidity. The greatest number of rust pustules/plant occurred when sedge was in close proximity to elderberry plants, suggesting that eradication of sedge within the plant rows would decrease pustule frequency and reduce the severity of infection.

Elderberry plant response to $P$. sambuci varied by rust-infection level. When young, potted elderberry plants averaged 3 to 6 rust pustules/plant, the number of leaves increased during the growing season and shoot dry weight was not adversely affected by rust. However, field-grown elderberry plants heavily infected with rust (137 pustules/cane) lost nearly twice as many leaves as controls during the growing season, indicating rust-induced defoliation. Shoot dry weight of these heavily infected canes was also $32 \%$ less than that of controls.

Fruiting characteristics of elderberry plants also varied, depending on the number of rust pustules. First and last harvest dates were advanced by the high level of rust infection on 'Wyldewood' elderberry canes, but not by low pustules numbers $(<6$ pustules/plant) on 'Bob Gordon' or 'Ozark' plants. Similarly, berry yields were not significantly different at low infection levels, even though rust-infected 'Bob Gordon' plants had a $31 \%$ reduction in yield with an estimated $\$ 440 /$ ha loss of income. Heavilyinfected 'Wyldewood' canes had a significant loss in berry yield (47\%) and potential 
income (\$2,295/ha), assuming a conservative estimate of five canes/plant and a selling price of $\$ 4.40 / \mathrm{kg}$ fruit.

Puccinia rust did not significantly alter soluble solids, $\mathrm{pH}$, or titratable acidity of berry puree. However, in all experiments, soluble solids of berry puree from rust infected plants were 0.6 to $0.9^{\circ}$ Brix lower than that of puree from infected plants. Soluble solid content of elderberry fruit is already generally low, therefore processors of elderberry products would incur additional costs for sweeteners as a result of rust infected plants. Thus, elderberry rust affects economic returns of processors as well as growers. In the final study, the causal organism for leaf spot disease was investigated. Colletotrichum salicis was isolated from necrotic lesions on elderberry leaflets in 2015. In 2016, elderberry plants were inoculated with $C$. salicis with leaf spots observed 19 days later. From diseased leaf spot lesions, fungal pathogens were re-isolated from inoculated plants as well as control plants. Two other Colletotrichum species C. kahawae subsp. ciggaro and C. aenigma, were recovered. Therefore, Colltotrichum species in background inocula naturally occur in Missouri. All three species appear similar in terms of symptoms, isolates, and spore morphology, making it difficult to determine the casual agent based upon morphology. 